\title{
Strategy of port baseline surveys (PBS) in the Adriatic Sea
}

\author{
Romina Kraus $^{\mathrm{a}, *, 1}$, Živana Ninčević-Gladan ${ }^{\mathrm{b}, 1}$, Rocco Auriemma ${ }^{\mathrm{c}}$, Mauro Bastianini ${ }^{\mathrm{d}}$, \\ Luca Bolognini $^{\mathrm{e}}$, Marina Cabrini ${ }^{\mathrm{c}}$, Magdalena Cara ${ }^{\mathrm{f}}$, Marijeta Čalić ${ }^{g}$, Alessandra Campanelli ${ }^{\mathrm{e}}$, \\ Ivan Cvitkovićb ${ }^{\mathrm{b}}$, Marija Despalatović ${ }^{\mathrm{b}}$, Branko Dragičević ${ }^{\mathrm{b}}$, Dragana Drakulovićch ${ }^{\mathrm{h}}$, Jakov Dulčić ${ }^{\mathrm{b}}$, \\ Vesna Flander-Putrle ${ }^{\mathrm{i}}$, Fabio Grati ${ }^{\mathrm{e}}$, Mateja Grego ${ }^{\mathrm{i}}$, Federica Grilli ${ }^{\mathrm{e}}$, Andrej Jaklin ${ }^{\mathrm{a}}$, \\ Ivica Janekovic $^{\mathrm{j}}{ }^{, \mathrm{k}}$, Jerina Kolitari ${ }^{\mathrm{f}}$, Lovrenc Lipej ${ }^{\mathrm{i}}$, Erika Magaletti ${ }^{1}$, Mauro Marini ${ }^{\mathrm{e}}$, \\ Sanja Matić-Skoko ${ }^{\mathrm{b}}$, Borut Mavrič ${ }^{\mathrm{i}}$, Josip Mikušm ${ }^{\mathrm{m}}$, Patricija Mozetič ${ }^{\mathrm{i}}$, Martina Orlando-Bonaca ${ }^{\mathrm{i}}$, \\ Slavica Petovićh ${ }^{\text {, Robert Precali }}{ }^{\mathrm{a}}$, Nastjenjka Supića ${ }^{\mathrm{a}}$, Benedetta Trabucco ${ }^{1}$, Ana Travizi ${ }^{\mathrm{a}}$, \\ Ante Žuljević ${ }^{b}$

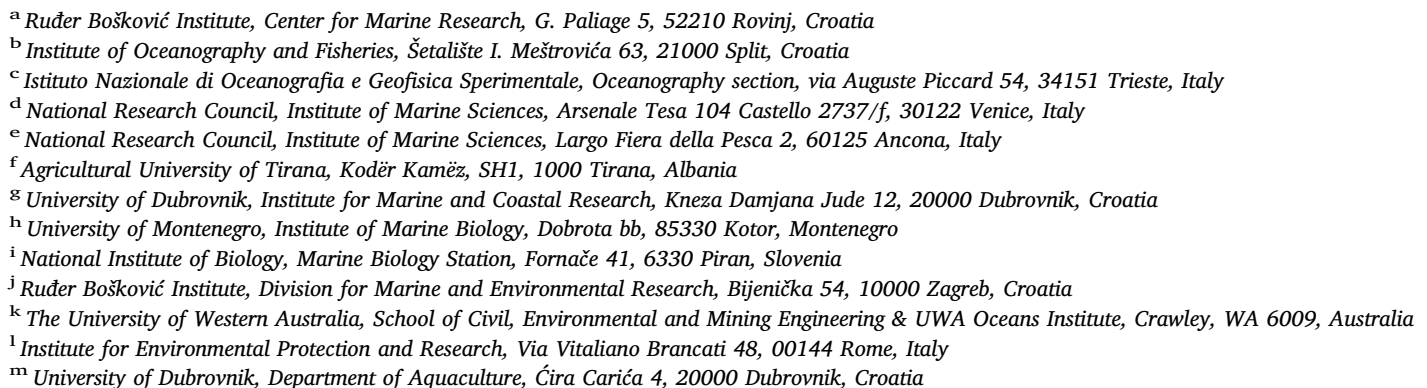

\section{A R T I C L E I N F O}

\section{Keywords:}

Adriatic Sea

Ballast water

Port baseline surveys

Non-indigenous species

Harmful aquatic organisms and pathogens BALMAS

\begin{abstract}
A B S T R A C T
Port baseline surveys (PBS) provide species inventories in and around ports, with a focus on non-indigenous species that may have been introduced by vessels, primarily via ballast water. PBS are an essential tool to support effective management strategies for non-indigenous as well as native harmful aquatic organisms and pathogens (HAOP). This paper describes the methodology of PBS that were conducted in 12 Adriatic ports. The PBS employed existing protocols that were adapted to meet the characteristics of the Adriatic sites. Their results are reported in several papers included in this special issue, each of which is devoted to a specific community. An overview of existing surveys protocols - which provide valuable support to decision-making and to design effective monitoring of non-indigenous species - is also supplied.
\end{abstract}

\footnotetext{
* Corresponding author.

E-mail addresses: kraus@cim.irb.hr (R. Kraus), nincevic@izor.hr (Ž. Ninčević-Gladan), rauriemma@inogs.it (R. Auriemma), mauro.bastianini@ismar.cnr.it (M. Bastianini), luca.bolognini@an.ismar.cnr.it (L. Bolognini), mcabrini@inogs.it (M. Cabrini), magdacara@ubt.edu.al (M. Cara), marijeta.calic@unidu.hr (M. Čalić), a.campanelli@ismar.cnr.it (A. Campanelli), cvite@izor.hr (I. Cvitković), mare@izor.hr (M. Despalatović), brankod@izor.hr (B. Dragičević), ddragana@t-com.me (D. Drakulović),dulcic@izor.hr (J. Dulčić), Vesna.FlanderPutrle@nib.si (V. Flander-Putrle), f.grati@ismar.cnr.it (F. Grati), Mateja.Grego@nib.si (M. Grego), federica.grilli@an.ismar.cnr.it (F. Grilli), jaklin@cim.irb.hr (A. Jaklin), ivica@irb.hr, ivica.janekovic@uwa.edu (I. Janeković), j.kolitari@gmail.com (J. Kolitari), Lovrenc.Lipej@mbss.org (L. Lipej), erika.magaletti@isprambiente.it (E. Magaletti), m.marini@ismar.cnr.it (M. Marini), sanja@izor.hr (S. Matić-Skoko), Borut.Mavric@mbss.org (B. Mavrič), josip.mikus@unidu.hr (J. Mikuš),

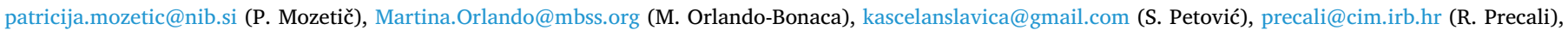
supic@cim.irb.hr (N. Supić), benedetta.trabucco@isprambiente.it (B. Trabucco), travizi@cim.irb.hr (A. Travizi), zuljevic@izor.hr (A. Žuljević).

1 These authors contributed equally to the work.
} 


\section{Introduction}

Non-indigenous species (NIS) are organisms that have (un)intentionally been moved out of their natural range as a result of human activities. Some fail to adjust to the (a)biotic conditions of the new site, others settle without inducing adverse effects on recipient habitats, and some adapt so efficiently that they induce irreversible changes in the new environment; the latter organisms have been called invasive alien species (IAS; Vitousek et al., 1996; Olenin et al., 2010). Since the 1990s, the intentional or accidental transport and introduction of aquatic species to new areas is perceived as a major threat to biological diversity (e.g., Hewitt and Martin, 2001 and references within). Coastal environments worldwide are considered as the most heavily invaded aquatic ecosystems, due to maritime traffic (Carlton and Geller, 1993; Grosholz, 2002).

Although reliable evidence for the economic impact of IAS is fairly limited, adverse effects of aquatic invasive species have been estimated to cost Europe at least $€ 2.2$ billion per year (Kettunen et al., 2009). After their introduction and spread, substantial human and financial resources are needed to eradicate IAS, or at least stop their further spread and repair the damage. Therefore, prevention is the most effective measure both in economic and environmental terms. An important step towards NIS management was taken in 2004, when the International Maritime Organization (IMO) adopted the International Convention for the Control and Management of Ships' Ballast Water and Sediments (BWM Convention; IMO, 2004). The Convention, which entered into force 13 years later, on 8 September 2017, requires all ships to adopt a Ballast Water and Sediments Management Plan and to manage their ballast water (bw) according to specific procedures, calling on its Parties to monitor the effects of BWM in their waters individually or jointly (IMO, 2005). In the past decade, the European Commission has issued several regulatory instruments to address the problems posed by NIS, including the Strategy on Invasive Species (EC, 2008a), the Marine Strategy Framework Directive (EC, 2008b), the Biodiversity Strategy (EC, 2011), and the Regulation on the Prevention and Management of the Introduction and Spread of Invasive Alien Species (EU, 2014), all of which rely on national and regional NIS inventories for their implementation (Marchini et al., 2015).

According to the BWM Convention, all aquatic organisms "which, if introduced into the sea including estuaries, or into fresh water courses, may create hazards to the environment, human health, property or resources, impair biological diversity or interfere with other legitimate uses of such areas" are harmful aquatic organisms and pathogens (HAOP). HAOP thus include all potentially harmful NIS, cryptogenic and impacting native aquatic species, including pathogens (David et al., 2013; Gollasch et al., 2015). The inclusion of native species is in line with recent findings that the effect of a native species which has become invasive can be stronger than that of an IAS (Katsanevakis et al., 2014).

It is widely acknowledged that scientifically validated and continuously updated and maintained databases are the most reliable source of information of NIS status, population dynamics, and ecology, and that they can provide a strong basis for the adoption of control measures (Genovesi, 2001; Olenin et al., 2014).

Investigation of the NIS described in the Mediterranean Sea indicated that their numbers are likely to be grossly underestimated, due to the spatial and temporal limitations of surveys as a result of human resource and/or budget constraints (Galil, 2009; Galil et al., 2016). Moreover, data accuracy seems to depend on readily available taxonomic expertise and to be mostly limited to large, conspicuous species, which are easily distinguished from the native biota, whereas smaller species remain largely unrecognized and undetected (Galil, 2009). Identification also appears to be higher for more accessible and easer to sample benthic species found in frequently sampled or fished coastal areas, which are extensively studied; new arrivals are thus more likely to be detected, unlike pelagic species in open sea.
Except for documented intentional introductions through culture and stocking activities, there is limited direct evidence for NIS pathways such as vessels and vectors like biofouling and bw (Ruiz et al., 2000). Notably, NIS introduction patterns can be investigated i) by examination of the literature and/or specimen collections and ii) by field surveys targeting habitats and areas associated with their vectors (Hewitt et al., 1999; Coles and Eldredge, 2002; Ruiz and Hewitt, 2002). Although the literature and museum collections provide the broadest coverage for a given region, they are inconsistent in both scope and effort (Ruiz et al., 2000); as a result, information derived solely from these sources may provide misleading indications of vector strength and introduction rates (Coles et al., 1999; Hewitt et al., 1999). In contrast, field surveys involve direct sampling in the environment and offer the opportunity to control for any sampling biases; however, they often provide only a "snapshot" record with narrow temporal resolution (Campbell et al., 2007).

Port Biological Baseline Surveys (PBBS) are monitoring surveys capable of supporting NIS and native HAOP management strategies (Bishop and Hutchings, 2011; Olenin et al., 2016). Their aim is to provide inventories of aquatic species in and around commercial ports frequented by ships carrying bw, with a focus on the assessment of the presence, abundance, and distribution of NIS that may have been introduced by vessels (Awad et al., 2014). PBBSs can: i) provide a valuable detection system for target species, facilitating species eradication before their proliferation and spread; ii) provide a baseline of native and NIS biodiversity to identify future new introductions; iii) help investigate invasion patterns in relation to abiotic and biotic factors; and iv) provide information on the effects of invasions (Bishop and Hutchings, 2011). PBBS differ in their scope, scale, and complexity, and can range from rapid surveys of certain target species to broader or fullscale taxonomic investigations. Moreover, PBBS may often be the only source of dependable information on the presence of target taxa and the principal basis for risk assessments and administrative decision-making. Accordingly, it is essential for surveys to use the best available scientific knowledge, where possible following a standardized procedure to allow comparison of bioinvasion patterns across space and time (e.g., Hewitt and Martin, 2001; Awad et al., 2014).

This paper details the design plan of the port baseline surveys (PBS) conducted in 12 Adriatic ports. The PBS protocol, which was based on the CRIMP protocols, was adapted to the characteristics of the Adriatic ports. The PBS data were used to set up the Adriatic HAOP database. The findings are reported in several papers of this special issue, each of which regards a specific community. The protocol devised for the Adriatic ports surveys is provided as Supplementary material (Appendix A).

\section{Material and methods}

\subsection{Protocol selection}

The protocol to be employed in the Adriatic PBS was devised taking into consideration the main approaches used in surveys of aquatic species. In particular, five major approaches have been adopted in different regions, providing detection of $>1185$ non-indigenous, 735 cryptogenic, and 15,315 native species up to 2007 in 19 countries, as follows (Campbell et al., 2007):

(1) Revised protocols for baseline port surveys for introduced marine species: survey design, sampling protocols, and specimen handling were developed by Hewitt and Martin (2001) while at the CRIMP (Commonwealth Scientific and Industrial Research Organization, Centre for Research on Introduced Marine Pests), hereinafter CRIMP protocols,

(2) Rapid assessment survey protocols for introduced, cryptogenic, and native species (e.g., Cohen et al., 2005; Ashton et al., 2006; Minchin et al., 2006), 
(3) Bernice P. Bishop Museum protocols for the detection and determination of the distribution of introduced, cryptogenic, and native species and for their invasion pathways and vectors (e.g., Coles et al., 1999; Paulay et al., 2002),

(4) Chilean aquaculture surveys focusing on a single target species (see Campbell et al., 2007), and

(5) Passive sampling method employing artificial substrates for passive collection of fouling epibiotic communities to detect species introduced in ports, determine their distribution patterns and potential threats, monitor vector patterns, and serve as an early warning tool (e.g., Ruiz and Hewitt, 2002; Wyatt et al., 2005).

These protocols are quantitative, qualitative, or a mixture of the two, and mostly involve sampling at locations that are potential inoculation sites, e.g. ports, marina areas, and aquaculture farms (Campbell et al., 2007). The CRIMP protocols and some of the Bernice P. Bishop Museum protocols, which use a combination of qualitative and quantitative approaches, and passive sampling, which uses only quantitative approaches, do not rely on taxonomic or specialist expertise at the time of collection, which makes teams easy to assemble and limits costs. Nonetheless, subsequent analyses do require taxonomic expertise. Furthermore, if the field work is performed by nonexperts, the material may be in non-ideal condition for species identification, because of potentially incorrect collection/preservation. Notably, quantitative methods enable comparison between sites and surveys, regardless of the personnel involved and provide a high-resolution spatial record, whereas rapid assessment survey protocols, some of the Bernice P. Bishop Museum protocols, and the Chilean aquaculture survey are based on a qualitative approach that requires trained field personnel with parataxonomic or taxonomic expertise. As a consequence, field teams may be more difficult to assemble and staff costs may be higher, while the ability to compare data from different surveys requires the involvement of the same team for all surveys. In addition, whereas qualitative approaches provide rapid evaluations of NIS at a site (e.g., Cohen et al., 2005; Ashton et al., 2006; Minchin et al., 2006) and are useful for initiating management or policy changes, quantitative approaches involve more field time, they supply statistically robust data that permit more complex assessments of bioinvasion patterns, and provide data for risk assessments, which require both presence and absence information (e.g., Hayes and Hewitt, 2000). Chilean aquaculture surveys have been developed specifically to provide risk and cost-benefit assessments in relation to species that had originally been introduced for farming purposes and had subsequently escaped (Hewitt et al., 2006). For instance, there is concern that abalone may be able to establish viable populations and influence the native biota, and surveys conducted by the diver observation technique aim to detect, note, and collect it (see Coles and Eldredge, 2002). However, a comprehensive study of the value of target species-oriented surveys has demonstrated that investigation of a single species makes a survey of limited use, since only a full inventory of the species at a site enables assessment of new arrivals and determination of spatial bioinvasion patterns while providing information that can support investigations of the impacts of introductions (Bishop and Hutchings, 2011).

Ideally, port surveys should involve collection of large numbers of specimens on several occasions, their identification by expert taxonomists to the species level, and the creation of a specimen catalogue at local research facilities or museums. However, such surveys are increasingly difficult to organize due to budget constraints and to the fact that taxonomic expertise is declining worldwide. Two possible solutions are as follows. One is to adopt new technologies, which are less labourintensive and enable inexpensive sample processing, as the basis for rapid and effective monitoring programmes (Lodge et al., 2006); notably, molecular assays, which can detect small amounts of NIS DNA in large water samples (Darling and Tepolt, 2008), can be combined with remote sensing, which enables identification of the habitats that are more vulnerable to invasion (Chong et al., 2001). Another possible solution is to undertake comprehensive sampling in a limited number of ports selected for their vulnerability or proximity to critical habitats, rather than focusing on a single species (Bishop and Hutchings, 2011).

PBBSs have been performed worldwide using the protocols described above or ad hoc-modified versions. For instance, the GloBallast guidelines (Awad et al., 2014) were based on the CRIMP protocols (Hewitt and Martin, 2001), while the HELCOM/OSPAR port sampling protocol (HELCOM/OSPAR, 2015) has been based on CRIMP and rapid assessment protocols (Pedersen et al., 2003; Cohen et al., 2005; Buschbaum et al., 2010) adapted to the HELCOM and OSPAR general marine monitoring protocols (HELCOM COMBINE manual, 2015; OSPAR CEMP Monitoring Manual).

The considerations reviewed above and the characteristics of the CRIMP protocols (Hewitt and Martin, 2001) led the current Adriatic PBS to be performed using the Hewitt and Martin protocols as the main guidelines.

The CRIMP protocols for PBS envisage specific procedures for data collection and measurements and provide for the adoption of sampling techniques appropriate for different port habitats:

(I) plankton and nekton (phytoplankton, zooplankton, mobile fauna and epifauna),

(II) hard substrates (mobile epifauna and fouling), and

(III) soft substrates, seagrass and algal beds (epibenthos, mobile epibenthos, benthic infauna, and dinoflagellate cysts).

In addition to the study of the biota, they include the measurement, analysis, or observation of environmental (temperature, salinity, turbidity, and sediment) and meteorological (air temperature, cloud cover, sea state and wind speed/direction) parameters at each sampling station.

These protocols ensure data comparability across sites, they have been used throughout the world as an aquatic bioinvasion survey standard, and have been adopted by governments and non-governmental organizations (Campbell et al., 2007). Another advantage is that they try to strike a balance between benefits (detection probability) and cost.

\subsection{Port selection}

The ports included in the PBS were selected based on the following criteria:

- they should provide a similar geographic coverage along the Adriatic coastline

- they should be severely affected by bw

- they should include at least the port with the most intense maritime traffic in each country

- they should take into account the human resources and capacity of the local institution(s) responsible for the PBS.

The ports included Bari (BI), Ancona (AN), Venice (VE), and Trieste (TR) in Italy; Koper (KO) in Slovenia; Pula (PU), Rijeka (RI), Šibenik (SI), Split (ST), and Ploče (PL) in Croatia; Bar (BA) in Montenegro; and Durrës (DU) in Albania (Fig. 1). Their data, including type, size, and depth of anchorage and cargo pier in the port, are reported in Table 1. Additional information is provided as Supplementary material (Appendix B).

\subsection{Selection of port survey areas}

The objectives of the CRIMP protocols are to detect non-indigenous, cryptogenic, and native species; determine species distribution, and identify NIS pathways and vectors. To meet these objectives, sampling was conducted in the port areas that are most likely to be affected and 


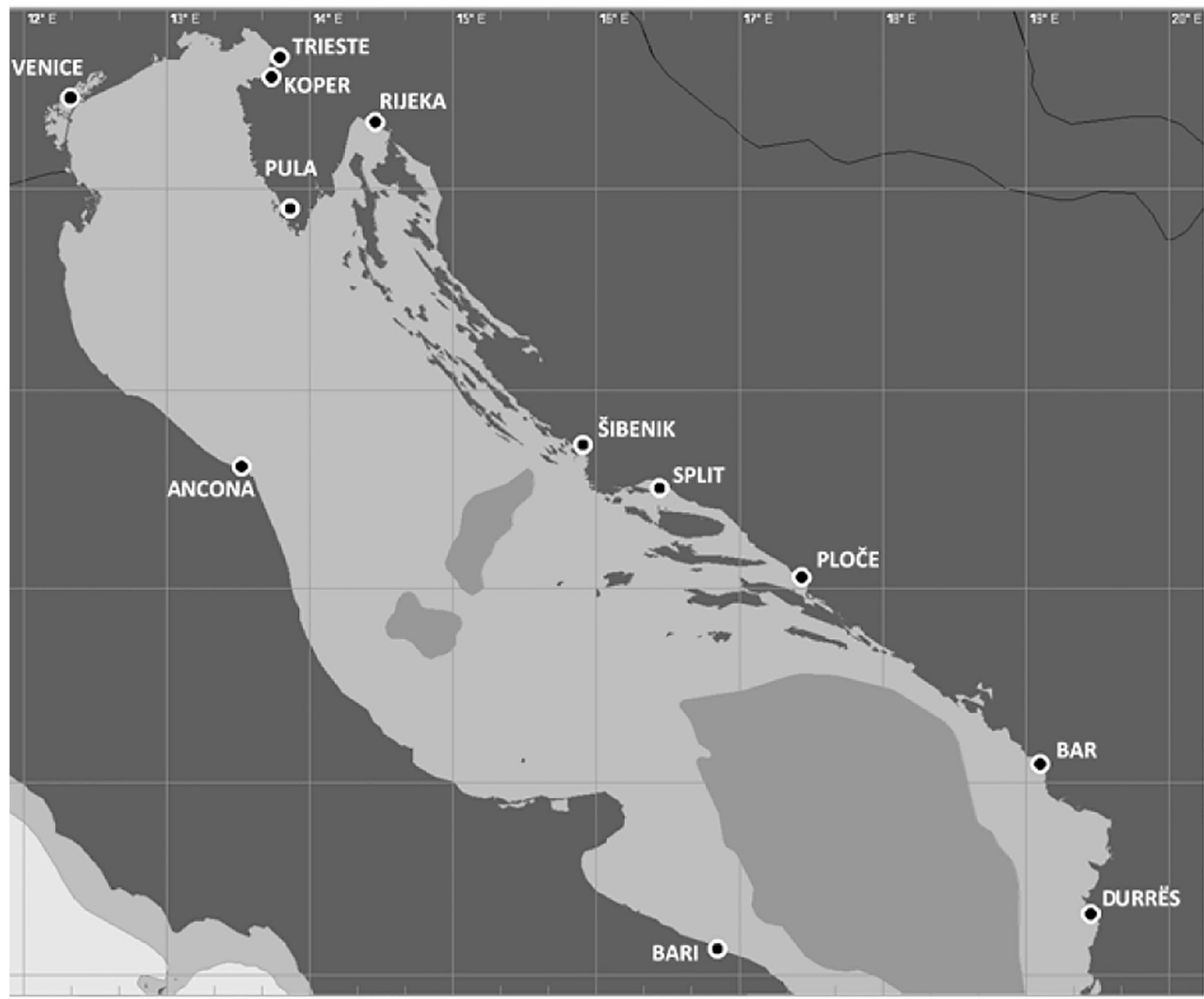

Fig. 1. Map of the Adriatic Sea with the 12 ports included in the PBS.

colonized based on ecological sampling practice and experimental design (Campbell et al., 2007). Accordingly, the areas to be sampled - i.e. those hosting commercial shipping facilities such as berths and wharves, which may be subject to unintentional bw discharge - were identified in close collaboration with port and maritime authorities (Table 2). In $9 / 12$ ports adjacent open sea areas, which can be assumed to be virtually or largely unaffected by bw, were selected as control sites. The water exchange rate with adjacent areas was another selection criterion, which led to favour areas characterized by more limited exchange, to investigate parameters such as dinoflagellate cysts in the port of Koper. The involvement of port and maritime authorities and their knowledge of local conditions, port activities, and shipping patterns helped with the selection of port survey areas and contributed to minimize scientific, logistic, and cost constraints.

\subsection{Selection of sampling sites}

The sampling sites were selected in port survey areas. To maximize the likelihood of detection of all the species inhabiting the port, they were selected so as to include a representative location of each type of habitat (e.g., soft and hard substrates, water column) found in the port, with a focus on active berths and breakwaters (Table 2). Again, control sites were selected at all ports except Šibenik, Split, and Ploče in areas outside the port that could be assumed to be under limited or no bw influence. At least three sampling sites per biotic parameter were selected in each port to meet the following objectives:

Table 1

Information on the 12 ports assessed in the PBS, including port type and size, and anchorage and cargo pier depth. Source: Ports.com (last accessed on 13th April 2018).

\begin{tabular}{|c|c|c|c|c|c|c|c|c|c|c|c|c|}
\hline PORT & Bari & Ancona & Venice & Trieste & Koper & Pula & Rijeka & Šibenik & Split & Ploče & Bar & Durrës \\
\hline Type & $\begin{array}{l}\text { coastal } \\
\text { breakwater }\end{array}$ & $\begin{array}{l}\text { coastal } \\
\text { breakwater }\end{array}$ & lagoon & $\begin{array}{l}\text { coastal } \\
\text { breakwater }\end{array}$ & $\begin{array}{l}\text { coastal } \\
\text { natural }\end{array}$ & $\begin{array}{l}\text { coastal } \\
\text { breakwater }\end{array}$ & $\begin{array}{l}\text { river } \\
\text { basin }\end{array}$ & $\begin{array}{l}\text { coastal } \\
\text { natural }\end{array}$ & $\begin{array}{l}\text { coastal } \\
\text { breakwater }\end{array}$ & $\begin{array}{l}\text { coastal } \\
\text { natural }\end{array}$ & $\begin{array}{l}\text { coastal } \\
\text { breakwater }\end{array}$ & $\begin{array}{l}\text { coastal } \\
\text { breakwater }\end{array}$ \\
\hline $\begin{array}{l}\text { Maximum length } \\
\qquad(>500<\text { feet })\end{array}$ & $<500$ & $>500$ & $>500$ & $>500$ & $<500$ & $>500$ & $<500$ & $<500$ & $>500$ & $<500$ & $>500$ & $<500$ \\
\hline Size & medium & small & large & large & small & very small & large & small & large & very small & medium & small \\
\hline Anchorage depth (metres) & $9.4-10$ & $11-12.2$ & $16-20$ & $18.6-19.8$ & $17.1-18.2$ & 11.12 .2 & $>23.2$ & $14-15.2$ & $11-12.2$ & $>23.2$ & $25-42$ & $6.4-7.6$ \\
\hline Cargo pier depth (metres) & $4.9-6.1$ & 7.1-9.1 & 9.1 & $11-12.2$ & $4.9-6.1$ & $3.4-4.6$ & $6.4-7.6$ & $4.9-6.1$ & $6.4-7.6$ & $3.4-4.6$ & $7-12.3$ & $6.4-7.6$ \\
\hline
\end{tabular}


Table 2

Type of sampling sites and priority ranking (based on CRIMP protocols; Hewitt and Martin, 2001) in port areas affected by ballast water (bw) and in open sea areas with no or little influence from ballast water (ref); *new location type (not included in the CRIPM protocols).

\begin{tabular}{ll}
\hline Port area & Priority \\
\hline Commercial shipping facilities (bw) & \\
Active berths & 1 \\
Inactive/disused wharves (ibw) & 1 \\
Channel markers (chm) & 1 \\
Tug and pilot vessel berths & 1 \\
Slipways & 1 \\
Dredge disposal and spoil ground & 2 \\
Breakwaters, groynes etc. for seaweed NIS & 3 \\
Adjacent areas outside the port (ref) & \\
Natural habitats & 2 \\
Exposed offshore areas & 2 \\
Anchorages (anc) & 1 \\
Exposed coastal areas* & 2 \\
\hline
\end{tabular}

(1) to provide a baseline assessment of the species found in the area,

(2) to gain insight into seasonal oceanographic variations,

(3) to seek specific chemical compounds related to the shipping industry,

(4) to investigate the sea circulation patterns, which affect the potential spread of organisms, and

(5) to ensure the feasibility and safety of measurement and sampling activities, including access by research vessels, vehicles and, especially, divers for manual sampling.

The list and basic information regarding the sampling stations, including coordinates, priority ranking (based on the CRIMP protocols), type of sediment, and parameters analysed are reported in Table 3. The name of each sampling site is a compound of three acronyms: port name (in capital letters, e.g. BA for Bar), type of sampling site as detailed in Table 2 (e.g. bw, anc, ref), and a suffix identifying the institution in charge of the PBS (internal reference coding, e.g. API, SL1, DR2). Only the sites in Kvarner Bay, where acoustic Doppler current profiler (ADCP) measurements were performed, are simply identified by a letter and a number. The map of each port and associated sampling sites is shown in Figs. 2-4.

\subsection{Selection of parameters}

The protocol used in the present PBS included determination of required and optional parameters, with some of the required parameters being considered as minimal or additional. Sampling frequency, intensity, and spatial coverage depended on the parameter being measured, the resources of the local partner, and port configuration. The scope and scale of the survey were determined primarily by human resource constrains; therefore, in order to meet the minimum requirements in each survey area, resources were shared among the partners.

The required parameters included:

(i) ABIOTIC parameters - minimal: temperature and salinity; additional: water transparency, nutrients, oxygen, chlorophyll $a$, and sediment (grain size and organic content), and

(ii) BIOTIC parameters - human pathogens (minimal: bacteria Escherichia coli, intestinal enterococci; additional: Vibrio cholerae serotypes 01 and 0139), plankton (phytoplankton, zooplankton, ichthyoplankton) including dinoflagellate cysts, mobile epibenthos and fish, benthic flora and fauna (infauna along horizontal transects and fouling along vertical transects; additional: meiofauna). Highlevel taxonomic identification was ensured by a cross-border network of qualified taxonomists and by capacity-building among the partners.
The optional parameters were investigated in a limited area and comprised chemical and physical measures. Chemical analyses of biocides (organotins) and disinfection by-products from chlorine treatment (trihalomethanes, haloacetonitriles and haloacetic acids) were performed in samples collected in Ancona, Bari, Koper, Rijeka, Split, Bar, and Durrës. Physical analyses, analysis of hydrographic conditions, geostrophic currents, and sea currents, CTD measurement, and numerical modelling involved the Kvarner Bay area (north-eastern Adriatic) and the ports of Pula and Rijeka (Fig. 5).

\subsection{Sampling strategy}

In the framework of the CRIMP protocols, the sampling effort varies as a function of the expected inoculation pressure and is greater in priority areas and limited at other sites. Furthermore, since a number of NIS are not widely distributed or abundant, sampling is performed with minimal sample replication but with maximal coverage of a study area or site (see Kish, 1995; McDonald, 2004), whereas replicate sampling is performed in cases where small-scale heterogeneity is expected to influence species detection (e.g., coring of dinoflagellate cysts, meiofauna). This design has demonstrated effectiveness in detecting small NIS populations in a port and in surrounding areas (e.g., Hewitt, 2002).

A major issue in PBS is taxonomic expertise, since misidentification of a species or its origin may result in its being reported as "new and undescribed" rather than as a possible NIS (see Carlton, 1999). The problem can be overcome by classifying species of unidentified origin as cryptogenic (origin unknown, sensu Carlton, 1996) until it is correctly attributed. Global taxonomic collaboration would clearly help this process (Hewitt, 2002; Pedersen et al., 2003; Campbell et al., 2007). By contrast, a species that fails to be observed is a "false negative". This can be due to a variety of reasons, including small sample size, inadequate sampling regimen for its detection of dispersion/distribution, and misidentification as a native species, and may have severe consequences (Campbell et al., 2007). Therefore, the PBS strategy should be devised and implemented by experts in the field, involve taxonomic experts who are well acquainted with native species, and provide for taxonomic identification at the level of species and possibly sub-species (Hewitt and Martin, 2001; Hewitt, 2002).

\section{Results}

The PBS protocol applied in the 12 Adriatic ports was based on the CRIMP protocols. The guidelines for the selection of ports, survey areas, and sampling sites; the scope of parameters, i.e. sampling intensity, frequency and timing; recommended and alternative sampling methods; sample processing and analyses were adopted after careful evaluation. A detailed description is provided as Supplementary material, Appendix A (Ninčević Gladan et al., 2014).

The investigation of ports involved biological and oceanographic parameters, essentially temperature and salinity. The PBS methodology and results are reported in several papers included in this issue. To enable comparison with existing data on the Adriatic biota, a regional approach was adopted. The papers address microbiological analysis of faecal pollution (Luna et al., this issue); phytoplankton (Mozetič et al., this issue), dinoflagellate cysts (Di Poi et al., submitted), zooplankton (Vidjak et al., this issue), macrozoobenthos on soft substrates (Travizi et al., under review), meiofauna (Semprucci et al., this issue) macrozoobenthos on hard substrates (Spagnolo et al., this issue), seaweeds (Petrocelli et al., this issue), and megafauna (Azzurro et al., this issue). Special attention was devoted to new and re-occurring NIS. Due to statistical constraints in each paper, some PBS results were not included in such articles. However, the complete dataset of each port is available in port-specific technical reports, which are summarized in the project's technical report of PBS activity (Ninčević Gladan et al., 2016 and references therein). The PBS findings regarding species - including information on the date and site of detection, habitat, and HAO (harmful 
Table 3

Sampling stations assessed in the 12 Adriatic ports, with information on location, coordinates, depth, priority ranking, type of sediment and analyses performed. The name of each sampling station is a compound of: port name (in capital letters), type of sampling site as detailed in Table 2 (e.g. bw, anc, ref), and a suffix identifying the institution in charge of the PBS (internal reference coding, e.g. API, SL1, DR2). At the bottom of the table, the sampling stations in Kvarner Bay, where ADCP measurements were taken, are simply identified by a letter and a number. Mi: microbial pollutants; Ph: phytoplankton; Dc: dinoflagellate cysts; Zo: zooplankton; Bs: soft bottom macrozoobenthos; Me: meiofauna; Bh: hard bottom macrozoobenthos; Sw: seaweeds; Mf: megafauna; O: Oceanographic features; C: Chemical port baseline surveys; na: data not available, because the parameter was not analysed or analysis was not envisaged; + : results reported in separate papers of this special issue and in technical reports; grey fields: results available in technical reports, not in a paper of this special issue.

\begin{tabular}{|c|c|c|c|c|c|c|c|c|c|c|c|c|c|c|c|c|c|c|}
\hline Country & Port & Sampling station & Depth & Priority & Latitude & Longitude & Type of sediment & $\mathrm{Mi}$ & $\mathrm{Ph}$ & Dc & Zo & Bs & Me & $\mathrm{Bh}$ & Sw & Mf & 0 & C \\
\hline Italy & BARI & Blbw1 & $10.0-12.0$ & 1 & $41^{\circ} 08^{\prime} 19.89^{\prime \prime} \mathrm{N}$ & $16^{\circ} 51^{\prime} 57.30^{\prime \prime} \mathrm{E}$ & Detritic & + & + & + & + & + & na & + & + & + & + & + \\
\hline Italy & BARI & Blbw2 & $4.5-7.5$ & 1 & $41^{\circ} 08^{\prime} 00.17^{\prime \prime} \mathrm{N}$ & $16^{\circ} 52^{\prime} 05.92^{\prime \prime} \mathrm{E}$ & Detritic & + & + & + & + & + & na & + & + & + & + & + \\
\hline Italy & BARI & Blbw3 & $3.5-4.5$ & 1 & $41^{\circ} 08^{\prime} 20.59^{\prime \prime} \mathrm{N}$ & $16^{\circ} 50^{\prime} 55.59^{\prime \prime} \mathrm{E}$ & Detritic & + & + & + & + & + & na & + & + & + & na & + \\
\hline Italy & BARI & Blref4 & $27.0-29.5$ & 2 & $41^{\circ} 09^{\prime} 02.22^{\prime \prime} \mathrm{N}$ & $16^{\circ} 51^{\prime} 26.77^{\prime \prime E}$ & Sand & + & + & na & + & na & na & na & na & na & + & na \\
\hline Italy & BARI & Blref5 & $23.0-26.0$ & 2 & $41^{\circ} 09^{\prime} 03.48^{\prime \prime} \mathrm{N}$ & $16^{\circ} 50^{\prime} 44.35^{\prime \prime E}$ & Sand & + & + & na & + & na & na & na & na & na & na & na \\
\hline Italy & BARI & Blref8 & $28.0-30.0$ & 2 & $41^{\circ} 09^{\prime} 00.58^{\prime \prime} \mathrm{N}$ & $16^{\circ} 52^{\prime} 07.90^{\prime \prime} \mathrm{E}$ & Sand & + & + & na & + & na & na & na & na & na & + & na \\
\hline Italy & ANCONA & ANancAPI & $13.0-16.0$ & 1 & $43^{\circ} 40^{\prime} 29.72^{\prime \prime} \mathrm{N}$ & $13^{\circ} 24^{\prime} 34.37^{\prime \prime E}$ & Sand & + & + & + & + & + & + & + & + & + & + & na \\
\hline Italy & ANCONA & ANancMB & $26.0-28.0$ & 1 & $43^{\circ} 43^{\prime} 33.11^{\prime \prime} \mathrm{N}$ & $13^{\circ} 31^{\prime} 30.18^{\prime \prime} \mathrm{E}$ & Sand & + & + & na & + & na & + & na & na & na & + & na \\
\hline Italy & ANCONA & ANbwDS & $10.0-11.0$ & 1 & $43^{\circ} 37^{\prime} 12.97^{\prime \prime} \mathrm{N}$ & $13^{\circ} 29^{\prime} 48.20^{\prime \prime} \mathrm{E}$ & Mud & + & + & + & + & + & + & + & + & + & + & + \\
\hline Italy & ANCONA & ANbwLR & $5.0-6.0$ & 1 & $43^{\circ} 37^{\prime} 30.91^{\prime \prime} \mathrm{N}$ & $13^{\circ} 29^{\prime} 40.00^{\prime \prime} \mathrm{E}$ & Mud & + & + & + & + & + & + & + & + & + & + & + \\
\hline Italy & ANCONA & ANrefSL1 & $15.0-16.0$ & 2 & $43^{\circ} 41^{\prime} 21.54^{\prime \prime} \mathrm{N}$ & $13^{\circ} 26^{\prime} 30.80^{\prime \prime} \mathrm{E}$ & Sand & + & + & na & + & na & na & na & na & na & + & na \\
\hline Italy & ANCONA & ANrefSL2 & 20.0 & 2 & $43^{\circ} 42^{\prime} 27.10^{\prime \prime} \mathrm{N}$ & $13^{\circ} 29^{\prime} 04.97 " \mathrm{E}$ & Sand & + & + & na & + & na & na & na & na & na & + & na \\
\hline Italy & VENICE & VEancPTF & 16.0 & 1 & $45^{\circ} 18^{\prime} 49.79^{\prime \prime} \mathrm{N}$ & $12^{\circ} 30^{\prime} 31.79 " \mathrm{E}$ & Sand & + & + & + & + & + & + & + & + & + & + & + \\
\hline Italy & VENICE & VEbw7M & 7.0 & 1 & $45^{\circ} 25^{\prime} 49.92^{\prime \prime} \mathrm{N}$ & $12^{\circ} 21^{\prime} 09.55^{\prime \prime E}$ & Mud & + & + & na & + & na & na & na & na & na & + & na \\
\hline Italy & VENICE & VEbwiN & 5.0 & 1 & $45^{\circ} 26^{\prime} 16.67^{\prime \prime} \mathrm{N}$ & $12^{\circ} 13^{\prime} 09.97^{\prime \prime} \mathrm{E}$ & Mud & + & + & na & + & + & + & + & na & na & + & na \\
\hline Italy & VENICE & VEbwP1 & 12.0 & 1 & $45^{\circ} 26^{\prime} 13.17^{\prime \prime} \mathrm{N}$ & $12^{\circ} 18^{\prime} 39.98^{\prime \prime E}$ & Mud & + & + & + & + & + & + & + & + & + & + & + \\
\hline Italy & VENICE & VEbwW2 & 7.0 & 1 & $45^{\circ} 26^{\prime} 54.19^{\prime \prime} \mathrm{N}$ & $12^{\circ} 15^{\prime} 29.87^{\prime \prime} \mathrm{E}$ & Mud & + & + & + & + & + & + & + & + & + & + & + \\
\hline Italy & VENICE & VEbwW3 & 7.0 & 1 & $45^{\circ} 25^{\prime} 02.22^{\prime \prime} \mathrm{N}$ & $12^{\circ} 15^{\prime} 35.00^{\prime \prime} \mathrm{E}$ & Mud & + & + & + & + & + & + & + & na & na & + & + \\
\hline Italy & VENICE & VErefS1 & 14.0 & 2 & $45^{\circ} 23^{\prime} 26.75^{\prime \prime} \mathrm{N}$ & $12^{\circ} 27^{\prime} 24.16^{\prime \prime E}$ & Sand & + & na & + & na & na & na & na & na & na & + & + \\
\hline Italy & VENICE & VErefS2 & 13.0 & 2 & $45^{\circ} 21^{\prime} 09.67^{\prime \prime} \mathrm{N}$ & $12^{\circ} 28^{\prime} 58.52^{\prime \prime} \mathrm{E}$ & Sand & + & na & + & na & na & na & na & na & na & + & + \\
\hline Italy & VENICE & VErefW4 & 6.0 & 2 & $45^{\circ} 25^{\prime} 34.21^{\prime \prime N} \mathrm{~N}$ & $12^{\circ} 25^{\prime} 41.41^{\prime \prime} \mathrm{E}$ & Mud & + & + & + & + & na & na & na & na & na & + & + \\
\hline Italy & TRIESTE & TSbw1 & 18.5 & 1 & $45^{\circ} 38^{\prime} 01.08^{\prime \prime} \mathrm{N}$ & $13^{\circ} 45^{\prime} 09.24^{\prime \prime E}$ & Mud & + & + & + & + & + & + & + & + & + & + & na \\
\hline Italy & TRIESTE & TSbw2 & 16.0 & 1 & $45^{\circ} 37^{\prime} 47.22^{\prime \prime} \mathrm{N}$ & $13^{\circ} 46^{\prime} 10.98^{\prime \prime} \mathrm{E}$ & Mud & + & + & + & + & + & + & + & + & + & + & na \\
\hline Italy & TRIESTE & TSbw3 & 14.0 & 1 & $45^{\circ} 37^{\prime} 04.08^{\prime \prime} \mathrm{N}$ & $13^{\circ} 46^{\prime} 30.96^{\prime \prime} \mathrm{E}$ & Mud & + & + & + & + & + & + & + & + & + & + & na \\
\hline Italy & TRIESTE & TSbw4 & 14.0 & 1 & $45^{\circ} 36^{\prime} 41.04^{\prime \prime} \mathrm{N}$ & $13^{\circ} 46^{\prime} 30.96^{\prime \prime} \mathrm{E}$ & Mud & + & + & + & + & + & + & + & + & na & + & na \\
\hline Italy & TRIESTE & TSbwM & 16.0 & 1 & $45^{\circ} 37^{\prime} 29.40^{\prime \prime N} \mathrm{~N}$ & $13^{\circ} 46^{\prime} 06.60^{\prime \prime} \mathrm{E}$ & Mud & + & + & + & + & na & na & na & na & na & + & na \\
\hline Italy & TRIESTE & TSchm7 & 19.0 & 1 & $45^{\circ} 37^{\prime} 15.18^{\prime \prime} \mathrm{N}$ & $13^{\circ} 44^{\prime} 32.04^{\prime \prime} \mathrm{E}$ & Mud & + & + & + & + & na & na & na & na & na & + & na \\
\hline Italy & TRIESTE & TSrefC1 & 18.0 & 2 & $45^{\circ} 42^{\prime} 03.00^{\prime \prime} \mathrm{N}$ & $13^{\circ} 42^{\prime} 36.00^{\prime \prime} \mathrm{E}$ & Mud & + & + & + & + & na & na & na & na & na & + & na \\
\hline Slovenia & KOPER & KOanc4 & $18.7-19.2$ & 1 & $45^{\circ} 34^{\prime} 19.20^{\prime \prime} \mathrm{N}$ & $13^{\circ} 42^{\prime} 18.72^{\prime \prime} \mathrm{E}$ & Mud & + & + & na & + & na & na & na & na & na & + & na \\
\hline Slovenia & KOPER & KOanc4A & 17.0 & 1 & $45^{\circ} 33^{\prime} 48.66^{\prime \prime N}$ & $13^{\circ} 42^{\prime} 52.86^{\prime \prime} \mathrm{E}$ & Mud & na & na & + & na & na & + & na & na & na & na & + \\
\hline Slovenia & KOPER & KObw1 & $11.5-15.1$ & 1 & $45^{\circ} 33^{\prime} 06.48^{\prime \prime N}$ & $13^{\circ} 44^{\prime} 01.26^{\prime \prime} \mathrm{E}$ & Mud & + & + & na & + & na & + & na & na & na & + & na \\
\hline Slovenia & KOPER & KObw1A & 10.0 & 1 & $45^{\circ} 33^{\prime} 05.10^{\prime \prime} \mathrm{N}$ & $13^{\circ} 44^{\prime} 11.04^{\prime \prime E}$ & Mud & na & na & + & na & na & na & na & na & na & na & na \\
\hline Slovenia & KOPER & KObw1d & $7.0-9.0$ & 1 & $45^{\circ} 33^{\prime} 22.98^{\prime \prime} \mathrm{N}$ & $13^{\circ} 43^{\prime} 32.40 " \mathrm{E}$ & Mud & na & na & na & na & + & na & na & na & na & na & na \\
\hline Slovenia & KOPER & KObw2 & $13.7-14.2$ & 1 & $45^{\circ} 33^{\prime} 30.36^{\prime \prime} \mathrm{N}$ & $13^{\circ} 44^{\prime} 20.28^{\prime \prime} \mathrm{E}$ & Mud & + & + & na & + & na & + & na & na & na & + & na \\
\hline Slovenia & KOPER & KObw2A & 13.1 & 1 & $45^{\circ} 33^{\prime} 27.36^{\prime \prime} \mathrm{N}$ & $13^{\circ} 44^{\prime} 12.00^{\prime \prime} \mathrm{E}$ & Mud & na & na & + & na & na & na & na & na & na & na & + \\
\hline Slovenia & KOPER & KObw2d & $0-2.0$ & 1 & $45^{\circ} 33^{\prime} 52.62^{\prime \prime} \mathrm{N}$ & $13^{\circ} 44^{\prime} 38.28^{\prime \prime} \mathrm{E}$ & Surface of the piles & na & na & na & na & na & na & + & + & + & na & na \\
\hline Slovenia & KOPER & KObw3 & $16.6-19.5$ & 1 & $45^{\circ} 33^{\prime} 57.00^{\prime \prime} \mathrm{N}$ & $13^{\circ} 44^{\prime} 30.30^{\prime \prime} \mathrm{E}$ & Mud & + & + & na & + & na & + & na & na & na & + & na \\
\hline Slovenia & KOPER & KObw3A & 12.5 & 1 & $45^{\circ} 33^{\prime} 52.44^{\prime \prime} \mathrm{N}$ & $13^{\circ} 44^{\prime} 11.10^{\prime \prime E}$ & Mud & na & na & + & na & na & na & na & na & na & na & + \\
\hline Slovenia & KOPER & KObw5 & 19.1 & 1 & $45^{\circ} 33^{\prime} 54.84^{\prime \prime} \mathrm{N}$ & $13^{\circ} 43^{\prime} 52.44^{\prime \prime} \mathrm{E}$ & Mud & na & + & na & na & na & na & na & na & na & na & na \\
\hline Slovenia & KOPER & KObwPT & $0-2.0$ & 1 & $45^{\circ} 33^{\prime} 01^{\prime \prime} \mathrm{N}$ & $13^{\circ} 43^{\prime} 58^{\prime \prime} \mathrm{E}$ & Wall of terminal & na & na & na & na & na & na & + & + & + & na & na \\
\hline Slovenia & KOPER & KOref AN & $7.0-9.0$ & 2 & $45^{\circ} 34^{\prime} 16.50^{\prime \prime} \mathrm{N}$ & $13^{\circ} 43^{\prime} 55.86^{\prime \prime} \mathrm{E}$ & Mud & na & na & na & na & + & na & na & na & na & na & na \\
\hline Slovenia & KOPER & KOrefDR1 & $4.0-15.0$ & 2 & $45^{\circ} 35^{\prime} 10.32^{\prime \prime} \mathrm{N}$ & $13^{\circ} 42^{\prime} 24.30^{\prime \prime E}$ & Mud & na & na & na & na & na & na & na & na & + & na & na \\
\hline Slovenia & KOPER & KOrefDR2 & $7.0-9.0$ & 2 & $45^{\circ} 35^{\prime} 11.76^{\prime \prime} \mathrm{N}$ & $13^{\circ} 42^{\prime} 27.60^{\prime \prime} \mathrm{E}$ & Mud & na & na & na & na & + & na & na & na & na & na & na \\
\hline Slovenia & KOPER & KOrefS & $1.0-4.0$ & 2 & $45^{\circ} 33^{\prime} 04.98^{\prime \prime} \mathrm{N}$ & $13^{\circ} 45^{\prime} 05.94^{\prime \prime E}$ & Mud & na & na & na & na & na & na & na & na & + & na & na \\
\hline Slovenia & KOPER & KOrefS1 & $0.5-2.0$ & 2 & $45^{\circ} 33^{\prime} 00.18^{\prime \prime} \mathrm{N}$ & $13^{\circ} 45^{\prime} 11.58^{\prime \prime} \mathrm{E}$ & Mud & na & na & na & na & + & na & na & na & na & na & na \\
\hline Slovenia & KOPER & KOrefS2 & $0.5-2.0$ & 2 & $45^{\circ} 32^{\prime} 51.48^{\prime \prime} \mathrm{N}$ & $13^{\circ} 45^{\prime} 15.00^{\prime \prime} \mathrm{E}$ & Mud & na & na & na & na & + & na & na & na & na & na & na \\
\hline Slovenia & KOPER & KOrefS3 & $0.5-2.0$ & 2 & $45^{\circ} 32^{\prime} 41.28^{\prime \prime} \mathrm{N}$ & $13^{\circ} 45^{\prime} 15.00^{\prime \prime} \mathrm{E}$ & Mud & na & na & na & na & + & na & na & na & na & na & na \\
\hline Slovenia & KOPER & KOrefS4 & $0.5-2.0$ & 2 & $45^{\circ} 32^{\prime} 41.94^{\prime \prime} \mathrm{N}$ & $13^{\circ} 45^{\prime} 02.88^{\prime \prime} \mathrm{E}$ & Mud & na & na & na & na & + & na & na & na & na & na & na \\
\hline Slovenia & KOPER & KOrefS5 & $0.5-2.0$ & 2 & $45^{\circ} 32^{\prime} 32.70^{\prime \prime} \mathrm{N}$ & $13^{\circ} 44^{\prime} 58.14^{\prime \prime E}$ & Mud & na & na & na & na & + & na & na & na & na & na & na \\
\hline Slovenia & KOPER & KOrefS6 & $0.5-2.0$ & 2 & $45^{\circ} 32^{\prime} 29.64^{\prime \prime N}$ & $13^{\circ} 44^{\prime} 39.96^{\prime \prime E}$ & Mud & na & na & na & na & + & na & na & na & na & na & na \\
\hline Slovenia & KOPER & KOrefS7 & $0.5-2.0$ & 2 & $45^{\circ} 32^{\prime} 28.56^{\prime \prime} \mathrm{N}$ & $13^{\circ} 44^{\prime} 28.44^{\prime \prime E}$ & Mud & na & na & na & na & + & na & na & na & na & na & na \\
\hline Slovenia & KOPER & KOrefS8 & $0.5-2.0$ & 2 & $45^{\circ} 32^{\prime} 29.82^{\prime \prime} \mathrm{N}$ & $13^{\circ} 44^{\prime} 21.90^{\prime \prime} \mathrm{E}$ & Mud & na & na & na & na & + & na & na & na & na & na & na \\
\hline
\end{tabular}


Table 3 (continued)

\begin{tabular}{|c|c|c|c|c|c|c|c|c|c|c|c|c|c|c|c|c|c|c|}
\hline Country & Port & Sampling station & Depth & Priority & Latitude & Longitude & Type of sediment & Mi & $\mathrm{Ph}$ & Dc & Zo & Bs & Me & $\mathrm{Bh}$ & Sw & Mf & 0 & C \\
\hline Slovenia & KOPER & KOrefSK & $4.0-5.0$ & 2 & $45^{\circ} 34^{\prime} 11.22^{\prime \prime} \mathrm{N}$ & $13^{\circ} 44^{\prime} 16.74^{\prime \prime E}$ & Mud & na & na & na & na & na & na & na & na & + & na & na \\
\hline Slovenia & KOPER & KOrefZ & $7.0-9.0$ & 2 & $45^{\circ} 32^{\prime} 55.80^{\prime \prime} \mathrm{N}$ & $13^{\circ} 42^{\prime} 29.64^{\prime \prime} \mathrm{E}$ & Mud & na & na & na & na & + & na & na & na & na & na & na \\
\hline Croatia & PULA & PUbwC & $7.0-7.8$ & 1 & $44^{\circ} 51^{\prime} 59.46^{\prime \prime} \mathrm{N}$ & $13^{\circ} 49^{\prime} 41.82^{\prime \prime} \mathrm{E}$ & Detritic/pebbles/rock & + & + & + & + & + & na & + & + & + & + & na \\
\hline Croatia & PULA & PUbwS & $5.7-6.2$ & 1 & $44^{\circ} 53^{\prime} 30.54^{\prime \prime} \mathrm{N}$ & $13^{\circ} 48^{\prime} 07.74^{\prime \prime E}$ & Mud & + & + & + & + & + & na & + & + & + & + & na \\
\hline Croatia & PULA & PUchm & $12.1-12.5$ & 1 & $44^{\circ} 52^{\prime} 43.20^{\prime \prime} \mathrm{N}$ & $13^{\circ} 50^{\prime} 24.00^{\prime \prime} \mathrm{E}$ & Mud & + & + & + & + & na & na & na & na & + & + & na \\
\hline Croatia & PULA & PUref & $33.7-36.7$ & 2 & $44^{\circ} 52^{\prime} 33.78^{\prime \prime} \mathrm{N}$ & $13^{\circ} 47^{\prime} 34.74^{\prime \prime E}$ & Detritic & + & + & + & + & + & na & + & + & na & + & na \\
\hline Croatia & RIJEKA & RlbwB & $7.0-8.8$ & 1 & $45^{\circ} 19^{\prime} 42.42^{\prime \prime} \mathrm{N}$ & $14^{\circ} 25^{\prime} 50.16^{\prime \prime} \mathrm{E}$ & Mud/silt & + & + & + & + & + & na & + & + & + & + & + \\
\hline Croatia & RIJEKA & RlbwS & $7.3-8.2$ & 1 & $45^{\circ} 19^{\prime} 20.40^{\prime \prime} \mathrm{N}$ & $14^{\circ} 26^{\prime} 19.68^{\prime \prime} \mathrm{E}$ & Mud/silt & + & + & + & + & + & na & + & + & + & + & + \\
\hline Croatia & RIJEKA & RIchm & $56.7-57.2$ & 1 & $45^{\circ} 19^{\prime} 30.30^{\prime \prime} \mathrm{N}$ & $14^{\circ} 23^{\prime} 49.38^{\prime \prime E}$ & Sand & + & + & + & + & na & na & na & na & + & + & na \\
\hline Croatia & RIJEKA & RIref & $30.2-35.5$ & 2 & $45^{\circ} 18^{\prime} 51.06^{\prime \prime} \mathrm{N}$ & $14^{\circ} 28^{\prime} 08.82^{\prime \prime} \mathrm{E}$ & Detritic & + & + & + & + & + & na & + & + & na & + & + \\
\hline Croatia & ŠIBENIK & Slbw1 & 15.0 & 1 & $43^{\circ} 43^{\prime} 30.54^{\prime \prime} \mathrm{N}$ & $15^{\circ} 53^{\prime} 57.41^{\prime \prime} \mathrm{E}$ & Mud & + & + & + & + & + & na & + & + & + & + & na \\
\hline Croatia & ŠIBENIK & Slbw2 & 23.0 & 1 & $43^{\circ} 43^{\prime} 36.23^{\prime \prime} \mathrm{N}$ & $15^{\circ} 53^{\prime} 51.25^{\prime \prime E}$ & Mud & + & + & na & + & + & na & + & + & + & + & na \\
\hline Croatia & ŠIBENIK & Slbw3 & 33.0 & 1 & $43^{\circ} 44^{\prime} 37.68^{\prime \prime} \mathrm{N}$ & $15^{\circ} 52^{\prime} 50.77^{\prime \prime} \mathrm{E}$ & Mud & + & + & + & + & + & na & na & na & + & + & na \\
\hline Croatia & ŠIBENIK & SlbwB1 & 10.0 & 1 & $43^{\circ} 43^{\prime} 32.42^{\prime \prime} \mathrm{N}$ & $15^{\circ} 54^{\prime} 02.31^{\prime \prime E}$ & Sand & na & na & na & na & na & na & + & + & na & na & na \\
\hline Croatia & ŠIBENIK & SlbwB2 & 7.0 & 1 & $43^{\circ} 44^{\prime} 36.01^{\prime \prime} \mathrm{N}$ & $15^{\circ} 52^{\prime} 54.30^{\prime \prime} \mathrm{E}$ & Sand & na & na & na & na & na & na & + & + & na & na & na \\
\hline Croatia & SPLIT & STbw1 & 9.0 & 1 & $43^{\circ} 31^{\prime} 42.28^{\prime \prime} \mathrm{N}$ & $16^{\circ} 27^{\prime} 54.04^{\prime \prime E}$ & Sandy mud & na & na & na & na & na & na & + & + & na & na & na \\
\hline Croatia & SPLIT & STbw2 & 9.0 & 1 & $43^{\circ} 32^{\prime} 10.19^{\prime \prime} \mathrm{N}$ & $16^{\circ} 27^{\prime} 53.62^{\prime \prime E}$ & Sandy mud & na & na & na & na & na & na & + & + & na & na & na \\
\hline Croatia & SPLIT & STbwJ1 & 17.0 & 1 & $43^{\circ} 32^{\prime} 18.42^{\prime \prime} \mathrm{N}$ & $16^{\circ} 26^{\prime} 21.01^{\prime \prime} \mathrm{E}$ & Sandy mud & + & + & + & + & + & na & na & na & + & + & + \\
\hline Croatia & SPLIT & STbwK1 & 17.0 & 1 & $43^{\circ} 32^{\prime} 05.71^{\prime \prime} \mathrm{N}$ & $16^{\circ} 27^{\prime} 48.42^{\prime \prime E}$ & Sandy mud & + & + & + & + & + & + & na & na & + & + & na \\
\hline Croatia & SPLIT & STbwL1 & 10.0 & 1 & $43^{\circ} 31^{\prime} 40.98^{\prime \prime} \mathrm{N}$ & $16^{\circ} 28^{\prime} 07.75^{\prime \prime E}$ & Sandy mud & + & + & + & + & + & na & na & na & + & + & + \\
\hline Croatia & SPLIT & STbwL2 & 15.0 & 1 & $43^{\circ} 31^{\prime} 44.65^{\prime \prime} \mathrm{N}$ & $16^{\circ} 27^{\prime} 49.25^{\prime \prime E}$ & Sandy mud & + & + & + & + & + & + & na & na & na & + & + \\
\hline Croatia & PLOČE & PLbw1 & $9.8-11.7$ & 1 & $43^{\circ} 03^{\prime} 06.77^{\prime \prime} \mathrm{N}$ & $17^{\circ} 25^{\prime} 51.14^{\prime \prime E}$ & Sand, silt, and clay & + & + & + & + & + & na & na & na & + & + & na \\
\hline Croatia & PLOČE & PLbw3 & $11.0-12.8$ & 1 & $43^{\circ} 02^{\prime} 56.61^{\prime \prime} \mathrm{N}$ & $17^{\circ} 25^{\prime} 34.30^{\prime \prime E}$ & Sand, silt, and clay & + & + & + & + & + & na & na & na & + & + & na \\
\hline Croatia & PLOČE & PLbw5 & $15.0-17.0$ & 1 & $43^{\circ} 02^{\prime} 44.42^{\prime \prime} \mathrm{N}$ & $17^{\circ} 25^{\prime} 35.08^{\prime \prime} \mathrm{E}$ & Sand, silt, and clay & + & + & + & + & + & na & na & na & + & + & na \\
\hline Croatia & PLOČE & PLbwB1 & $11.0-12.8$ & 1 & $43^{\circ} 02^{\prime} 54.64^{\prime \prime} \mathrm{N}$ & $17^{\circ} 25^{\prime} 29.81^{\prime \prime E}$ & Sandy mud & na & na & na & na & na & na & + & + & na & na & na \\
\hline Croatia & PLOČE & PLbwB2 & 12.0 & 1 & $43^{\circ} 02^{\prime} 01.62^{\prime \prime} \mathrm{N}$ & $17^{\circ} 25^{\prime} 53.52^{\prime \prime E}$ & Sandy silt & na & na & na & na & na & na & + & + & na & na & na \\
\hline Croatia & PLOČE & PLbwKV & 12.0 & 1 & $43^{\circ} 02^{\prime} 00.61^{\prime \prime} \mathrm{N}$ & $17^{\circ} 25^{\prime} 54.54^{\prime \prime} \mathrm{E}$ & Sand, silt, and clay & + & + & + & + & + & na & na & na & + & + & na \\
\hline Montenegro & BAR & BAbw1 & 10.0 & 1 & $42^{\circ} 05^{\prime} 33.06^{\prime \prime} \mathrm{N}$ & $19^{\circ} 05^{\prime} 23.06^{\prime \prime E}$ & Sand-mud & + & + & na & + & - & - & - & - & + & + & na \\
\hline Montenegro & BAR & BAbw2 & 12.0 & 1 & $42^{\circ} 05^{\prime} 09.32^{\prime \prime} \mathrm{N}$ & $19^{\circ} 05^{\prime} 01.18^{\prime \prime E}$ & Sand-mud & + & + & na & + & - & - & + & + & + & + & na \\
\hline Montenegro & BAR & BAibw3 & 12.0 & 1 & $42^{\circ} 05^{\prime} 37.27^{\prime \prime} \mathrm{N}$ & $19^{\circ} 04^{\prime} 44.07^{\prime \prime} \mathrm{E}$ & Sand-mud & + & + & na & + & - & - & + & + & + & + & + \\
\hline Montenegro & BAR & BAref & 14.0 & 2 & $42^{\circ} 05^{\prime} 48.67^{\prime \prime} \mathrm{N}$ & $19^{\circ} 04^{\prime} 49.88^{\prime \prime} \mathrm{E}$ & Sand-mud & + & + & na & + & - & - & - & - & - & + & + \\
\hline Albania & DURRËS & DUbw1 & 9.0 & 1 & $41^{\circ} 18^{\prime} 17.72^{\prime \prime} \mathrm{N}$ & $19^{\circ} 27^{\prime} 15.37^{\prime \prime E}$ & Muddy sand & + & + & na & na & na & na & na & na & na & + & + \\
\hline Albania & DURRËS & DUbw2 & 10.0 & 1 & $41^{\circ} 18^{\prime} 32.65^{\prime \prime N}$ & $19^{\circ} 27^{\prime} 14.01^{\prime \prime E}$ & Muddy sand & + & + & na & na & na & na & na & na & na & + & + \\
\hline Albania & DURRËS & DUbw3 & 8.0 & 1 & $41^{\circ} 18^{\prime} 42.62^{\prime \prime} \mathrm{N}$ & $19^{\circ} 27^{\prime} 17.57^{\prime \prime E}$ & Muddy sand & + & + & na & na & na & na & na & na & na & + & + \\
\hline Albania & DURRËS & DUbw4 & 8.0 & 1 & $41^{\circ} 18^{\prime} 40.78^{\prime \prime N}$ & $19^{\circ} 27^{\prime} 07.02^{\prime \prime E}$ & Muddy sand & na & na & na & na & na & na & + & + & na & na & na \\
\hline Albania & DURRËS & DUbw5 & 10.0 & 1 & $41^{\circ} 18^{\prime} 18.02^{\prime \prime N}$ & $19^{\circ} 27^{\prime} 05.72 " \mathrm{E}$ & Muddy sand & na & na & na & na & na & na & + & + & na & na & na \\
\hline Albania & DURRËS & DUref6 & 17.5 & 2 & $41^{\circ} 18^{\prime} 03.9^{\prime \prime} \mathrm{N}$ & $19^{\circ} 27^{\prime} 36.5^{\prime \prime} \mathrm{E}$ & Muddy sand & + & + & na & na & na & na & na & na & na & na & na \\
\hline Croatia & KVARNER & B1 & 47.0 & na & $44^{\circ} 43^{\prime} 08.28^{\prime \prime} \mathrm{N}$ & $13^{\circ} 58^{\prime} 44.40^{\prime \prime} \mathrm{E}$ & Sand & na & na & na & na & na & na & na & na & na & na & na \\
\hline Croatia & KVARNER & B2 & 48.0 & na & $44^{\circ} 38^{\prime} 18.78^{\prime \prime} \mathrm{N}$ & $14^{\circ} 08^{\prime} 31.56^{\prime \prime} \mathrm{E}$ & Sand & na & na & na & na & na & na & na & na & na & na & na \\
\hline Croatia & KVARNER & B3 & 47.0 & na & $44^{\circ} 40^{\prime} 58.92^{\prime \prime} \mathrm{N}$ & $14^{\circ} 03^{\prime} 28.62^{\prime \prime} \mathrm{E}$ & Sand & na & na & na & na & na & na & na & na & na & na & na \\
\hline Croatia & KVARNER & s8 & 54.0 & na & $44^{\circ} 21^{\prime} 50.10^{\prime \prime} \mathrm{N}$ & $14^{\circ} 30^{\prime} 42.42^{\prime \prime} \mathrm{E}$ & Sand & na & na & na & na & na & na & na & na & na & na & na \\
\hline Croatia & KVARNER & s9 & 52.0 & na & $44^{\circ} 18^{\prime} 01.02^{\prime \prime} \mathrm{N}$ & $14^{\circ} 41^{\prime} 01.14^{\prime \prime E}$ & Sand & na & na & na & na & na & na & na & na & na & na & na \\
\hline
\end{tabular}

aquatic organisms) and/or NIS status - are reported in the BALMAS Port sampling database for HAOP, which is accessible online (http:// balmas.izvrs.si/balmas_haop/).

In line with the considerations reviewed above, some new methodologies were tested in parallel with traditional approaches, like a DNA-based method for rapid quantification of faecal bacteria (Luna et al., this issue) and a quantitative real-time PCR-based assay for species identification and quantification of toxic dinoflagellate cysts (Perini et al., this issue).

Furthermore, the results of the chemical analyses performed in seven of the 12 ports are reported separately (Romanelli et al. this issue). Biocides (organotins) and disinfection by-products from chlorine treatment (trihalomethanes, haloacetonitriles and haloacetic acids) released after bw treatment in vessels and cross-contamination with butyltin compounds through bw discharge were also investigated (Table 3).

ADCP measurements in Kvarner Bay (Fig. 5) provided insight into the water circulation patterns linking ports to the Adriatic circulation and into potential natural spread pathways of HAOP as opposed to NIS introduced via bw (Kraus et al., this issue, this issue). 

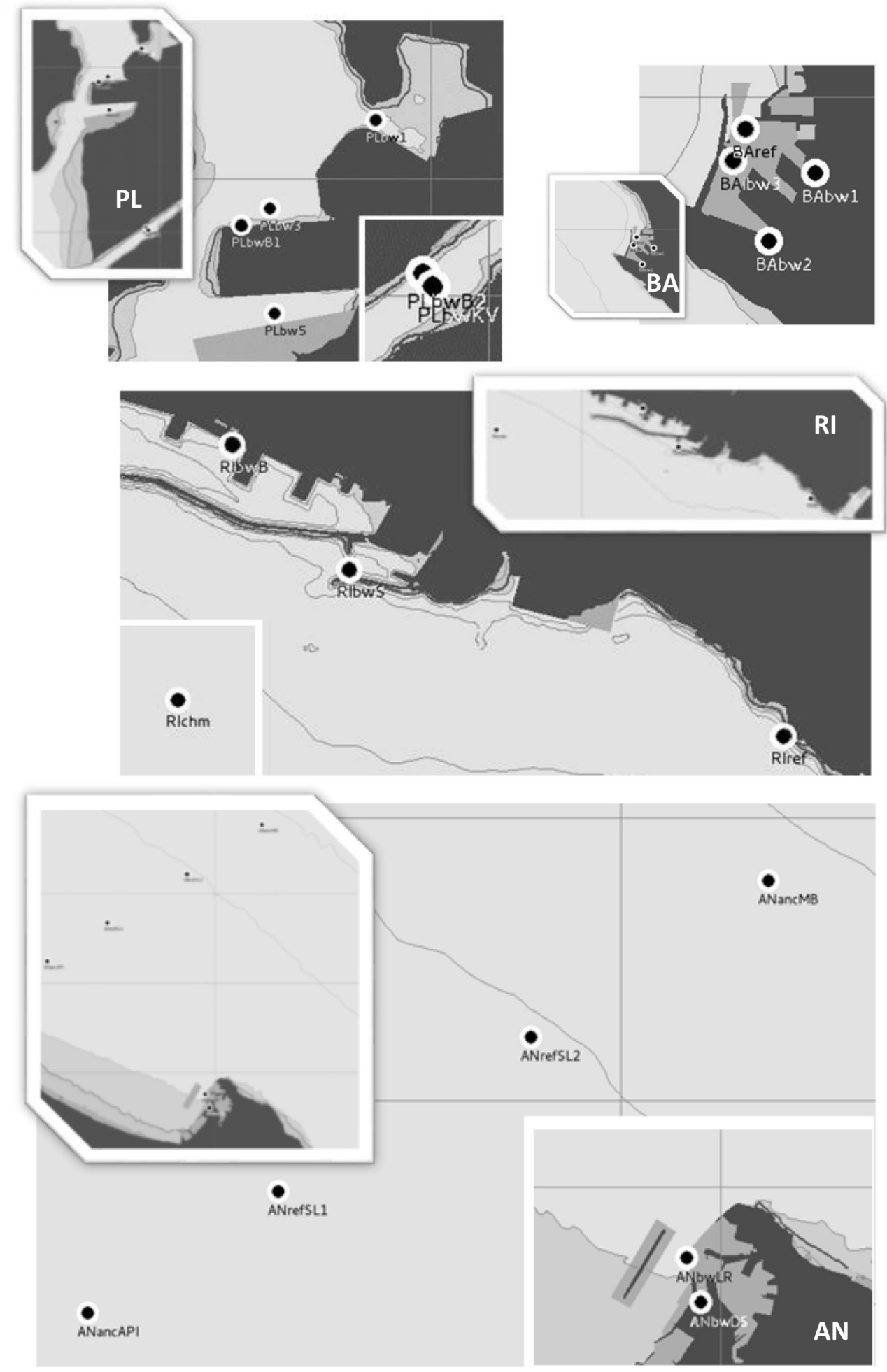

Fig. 2. Map of the ports of Ancona (AN), Bar (BA), Ploče (PL), and Rijeka (RI) and location of the sampling stations.

\section{Discussion}

PBSs were conducted in 12 Adriatic ports according to a specially devised monitoring protocol for NIS and HAOP. The protocol is proposed as a tool to standardize NIS and HAOP environmental monitoring in the Adriatic Sea according to the recommendations of the Marine Strategy Framework Directive and the BWM Convention (Bastianini et al., 2016). After the PBS, port monitoring was applied as a part of or in addition to regular national monitoring or as a separate investigation to collect data to meet BWM Convention requirements. The results were used to update the BALMAS Port sampling database for HAOP.

The Adriatic PBS protocol was based on the CRIMP protocols, with some significant modifications. The CRIMP protocols envisage the measurement of meteorological data besides the usual parameters and set out a list of target pest species; whereas the current protocol includes ichthyoplankton, E. coli, and intestinal enterococci as required 

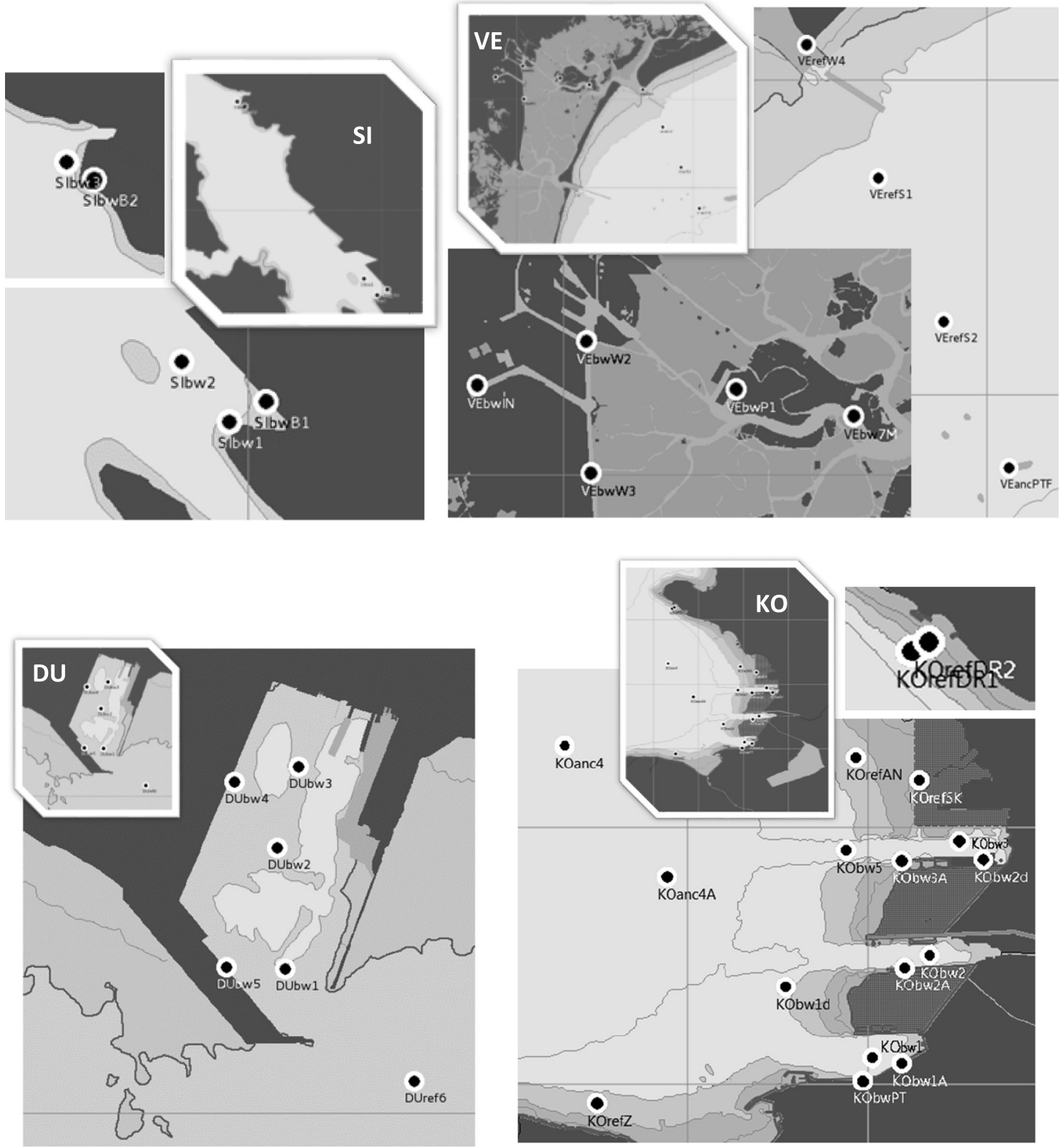

Fig. 3. Map of the ports of Durrës (DU), Koper (KO), Šibenik (SI), and Venice (VE) and location of the sampling stations.

parameters, water transparency, nutrients, oxygen, chlorophyll $a$, meiofauna, and $V$. cholerae serotypes 01 and 0139 as additional measures, and some chemical and physical factors as optional parameters. These features enable the current protocol to address the problem of bw in a comprehensive way and in line with IMO guidelines. Unlike the CRIMP protocols, where the sampling procedure and equipment, sample processing, specimen handling, and information/specimen archiving are regulated in fine detail, the Adriatic PBS protocol provides basic methodological guidelines for most parameters and makes no reference to archiving procedures or to adjustments for sampling conducted at specific locations. A further difference is that the sampling effort for the detection of rare species in the Adriatic protocol is at least three sampling sites per biological parameter (i.e. nine samples regardless of species frequency), as opposed to no $<20$ samples in the CRIMP protocols. Moreover, sampling frequency and timing are expressly established for each parameter in the Adriatic protocol, whereas they are not considered in the CRIMP protocols. Lastly, despite a similar reporting outline, the CRIMP protocols provide reporting format guidelines whereas the Adriatic protocol does not. Whereas the CRIMP format envisages detailed reporting of the NIS detected during the survey, including risk assessment, management, prevention, and description of any change compared with previous data regarding the native biota, the Adriatic reporting format contains a broader array of more varied information and includes objectives, a detailed presentation of both native biota and NIS data, a general assessment of the translocation risk, as well as recommendations and proposals for future surveys and monitoring efforts.

In conclusion, the Adriatic protocol reflects the assumption that a port is being investigated for the first time and takes into consideration the fact that the survey is performed by multiple institutions, each bringing to the task diverse skills and equipment; this, in particular, is why the sampling procedures are merely outlined and several 

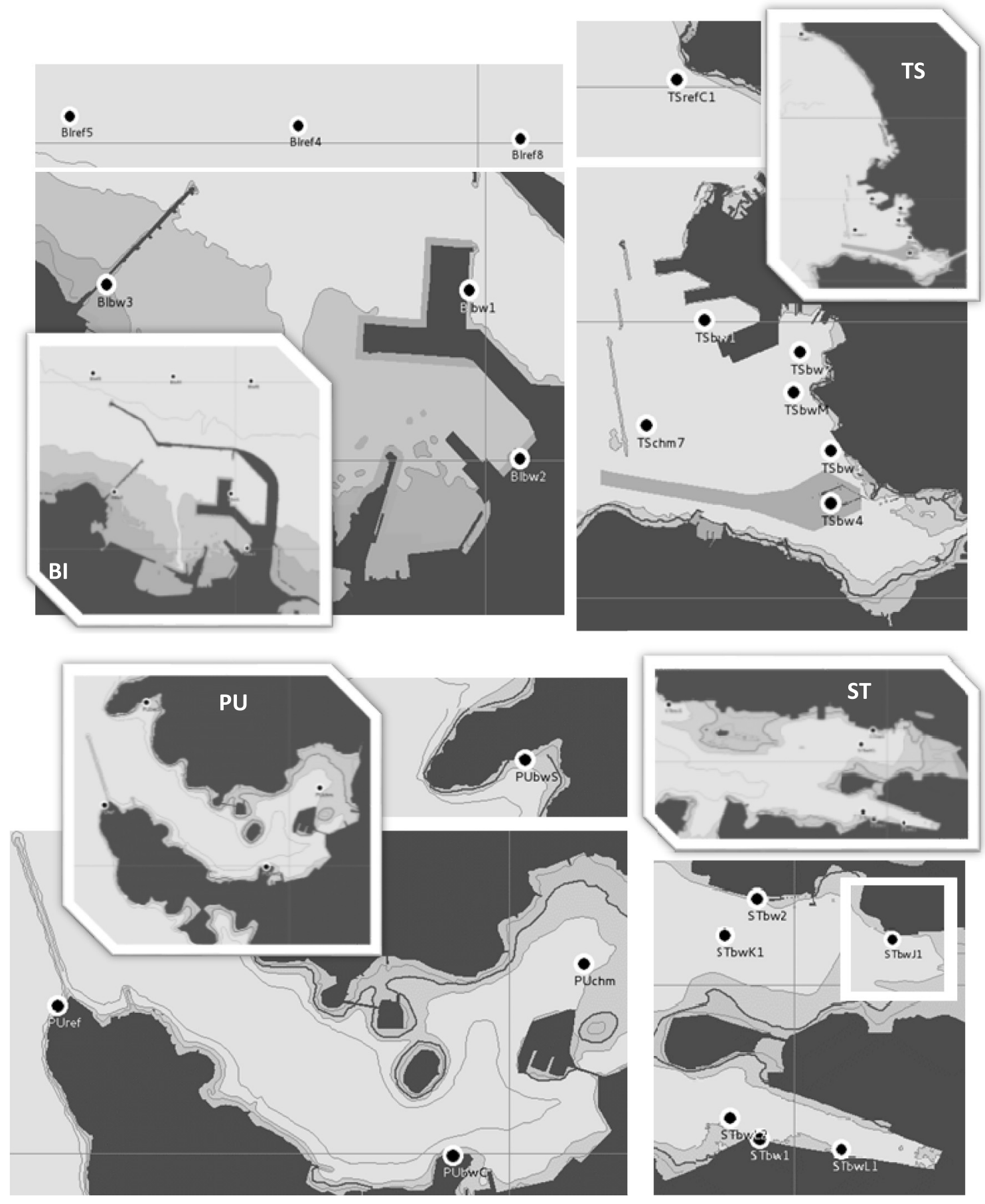

Fig. 4. Map of the ports of Bari (BI), Pula (PU), Split (ST), and Trieste (TS) and location of the sampling stations.

alternatives are provided.

Since the current PBS were limited to 12 ports, and the selection of parameters and sampling stations was guided by capacity constraints, additional work is required to expand and update the present findings regarding the biota in the Adriatic ports. Cross-border monitoring of ports, which are hotspots for NIS and HAOP, would provide valuable data. Although the protocol would benefit from more detailed sampling and processing guidelines - to enhance the consistency and comparability of the data collected in different ports - this would require some of the partners to abandon their routine procedures and adopt new ones, thus losing the comparability with their existing datasets. This issue goes beyond bw management in the Adriatic and has a wider, regional scope; as such, it affects general scientific research and monitoring endeavours in the Adriatic and deserves to be addressed accordingly.

Critically, continuous regional financing would enable assembling sufficient and adequate taxonomic expertise and sampling and processing personnel to provide an efficient HAOP early warning system and, where necessary, early response and adoption of remediation measures. Unless such financing is provided, protection from HAOP will be sporadic and inadequate, and remain an unattainable goal. 


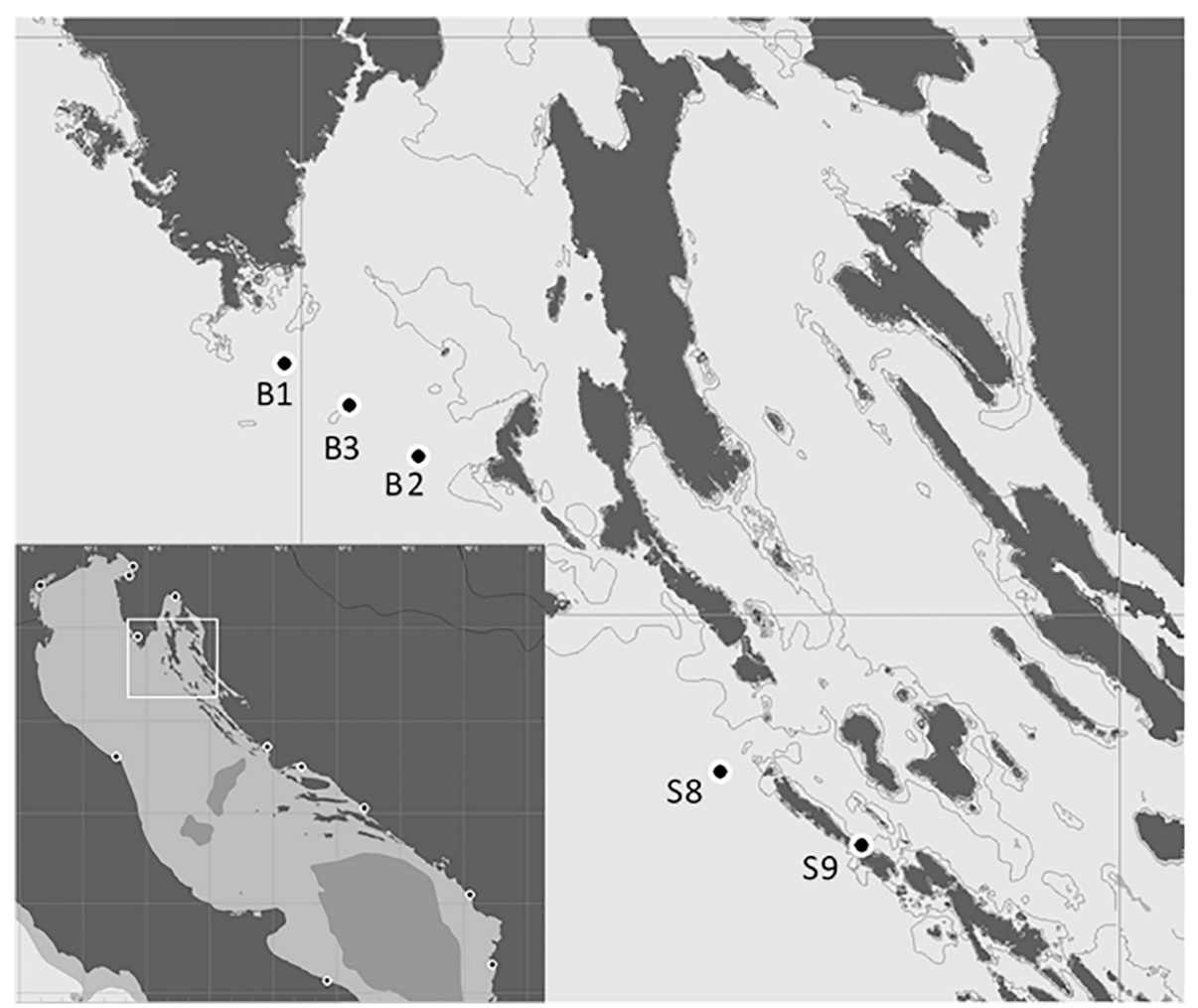

Fig. 5. Map of the sampling stations in Kvarner Bay, where acoustic Doppler current profiler (ADCP) measurements were performed as additional physical analyses.

\section{Acknowledgements}

This publication has been produced with the financial assistance of the IPA Adriatic Cross-Border Cooperation Programme - strategic project Ballast Water Management System for Adriatic Sea Protection (BALMAS). The contents of this publication are the sole responsibility of authors and can under no circumstances be regarded as reflecting the position of the IPA Adriatic Cross-Border Cooperation Programme Authorities.

We highly appreciate reviewers' constructive critique with insightful and precise recommendations.

\section{Appendix. Supplementary data}

Supplementary data to this article can be found online at https:// doi.org/10.1016/j.marpolbul.2018.08.067.

\section{References}

Ashton, G., Boos, K., Shucksmith, R., Cook, E., 2006. Rapid assessment of the distribution of marine non-native species in marinas in Scotland. Aquat. Invasions 1, 209-213. https://doi.org/10.3391/ai.2006.1.4.3.

Awad, A., Haag, F., Anil, A.C., Abdulla, A., 2014. GEF-UNDP-IMO GloBallast Partnerships Programme, IOI, CSIR-NIO and IUCN. Guidance on Port Biological Baseline Surveys. GEF-UNDP-IMO GloBallast Partnerships, London, UK. GloBallast Monograph No. 22.

Azzurro, E., Bolognini, L., Dragičević, B., Drakulović, D., Dulčić, J., Fanelli, E., Grati, F., Kolitari, J., Lipej, L., Magaletti, E., Marković, O., Matić-Skoko, S., Mavrič, B., Milone, N., Joksimović, A., Tomanić, J., Scarpato, A., Tutman, P., Vrdoljak, D., Zappacosta, F., 2018. Detecting the Occurrence of Indigenous and Non-indigenous Megafauna Through Fishermen Knowledge: A Complementary Tool to Coastal and Port Surveys. (This issue).

Bastianini, M., Pezzolesi, L., Magaletti, E., Azzurro, E., Pigozzi, S., Kraus, S., Mozetič, P., Gollasch, S., 2016. BALMAS Port Monitoring Protocol for NIS and HAOP in the Adriatic Sea. BALMAS Project. Work Package 5.2. (31 pp).

Bishop, M.J., Hutchings, P.A., 2011. How useful are port surveys focused on target pest identification for exotic species management? Mar. Pollut. Bull. 62, 36-42. https:// doi.org/10.1016/j.marpolbul.2010.09.014.

Buschbaum, C., Karez, R., Lackschewitz, D., Reise, K., 2010. Rapid assessment of neobiota in German coastal waters. Monitoring and Assessment Group. In: HELCOM MONAS 13/2010, Document 6/4.
Campbell, M.L., Gould, B., Hewitt, C.L., 2007. Survey evaluations to assess marine bioinvasions. Mar. Pollut. Bull. 55, 360-378. https://doi.org/10.1016/j.marpolbul. 2007.01.015.

Carlton, J.T., 1996. Biological invasions and cryptogenic species. Ecology 77, 1653-1655. https://doi.org/10.2307/2265767.

Carlton, J.T., 1999. Community assembly and historical biogeography in the North Atlantic Ocean: the potential role of human-mediated dispersal vectors. Hydrobiologia 503, 1-8. https://doi.org/10.1023/B:HYDR.0000008479.90581.e1.

Carlton, J.T., Geller, J.B., 1993. Ecological roulette: the global transport of non-indigenous marine organisms. Science 261, 70-82. https://doi.org/10.1126/science. 261.5117.78.

Chong, G.W., Reich, R.M., Kalkhan, M.A., Stohlgren, T.J., 2001. New approaches for sampling and modelling native and exotic plant species richness. West. N. Am. Naturalist 61, 328-335.

Cohen, A.N., Harris, L.H., Bingham, B.L., Carlton, J.T., Chapman, W., Lambert, C.C., Lambert, G., Ljubenkov, J.C., Murray, S.N., Rao, L.C., Reardon, K., Schwindt, E., 2005. Rapid assessment survey for exotic organisms in southern California bays and harbours, and abundance in port and non-port areas. Biol. Invasions 7, 995-1002. https://doi.org/10.1007/s10530-004-3121-1.

Coles, S.L., Eldredge, L.G., 2002. Nonindigenous species introductions on coral reefs: a need for information. Pac. Sci. 56, 191-209. https://doi.org/10.1353/psc. 2002. 0010 .

Coles, S.L., DeFelice, R.C., Eldredge, L.G., Carlton, J.T., 1999. Historical and recent in troductions of non-indigenous marine species into Pearl Harbor, Oahu, Hawaiian islands. Mar. Biol. 135, 147-158. https://doi.org/10.1007/s002270050612.

Darling, J.A., Tepolt, C.K., 2008. Highly sensitive detection of invasive shore crab (Carcinus maenas and Carcinus aestuarii) larvae in mixed plankton samples using polymerase chain reaction and restriction fragment length polymorphisms (PCRRFLP). Biol. Invasions 3, 141-152. https://doi.org/10.3391/ai.2008.3.2.4.

David, M., Gollasch, S., Leppäkoski, E., 2013. Risk assessment for exemptions from ballast water management - the Baltic Sea case study. Mar. Pollut. Bull. 75, 205-217. https://doi.org/10.1016/j.marpolbul.2013.07.031.

Di Poi, E., Kraus, R., Cabrini, M., Finotto, S., Flander-Putrle, V., Grego, M., Kužat, N., Ninčević Gladan, Ž., Pezzolesi, L., Riccardi, E., Bernardi Aubry, F., Bastianini, M., 2018. Dinoflagellate Resting Cysts From Surface Sediments of the Adriatic Ports: Distribution and Potential Spreading Patterns. (This issue. Under review).

EC, 2008a. Towards an EU strategy on invasive species. In: European Commission. COM/ 2008/789. European Commission, Brussels (10 pp).

EC, 2008b. Directive 2008/56/EC of the European Parliament and of the council of 17 June 2008 establishing a framework for community action in the field of marine environmental policy (Marine Strategy Framework Directive). Off. J. Eur. Communities L164, 19-40.

EC, 2011. Our life insurance, our natural capital: an EU biodiversity strategy to 2020. In: COM/2011/244. European Commission, Brussels (16 pp.).

EU, 2014. Regulation on the prevention and management of the introduction and spread of invasive alien species. In: PE-CONS 70/14. European Parliament and Council, 
Brussels (11 pp.).

Galil, B.S., 2009. Taking stock: inventory of alien species in the Mediterranean Sea. Biol. Invasions 11, 359-372. https://doi.org/10.1007/s10530-008-9253-y.

Galil, B.S., Marchini, A., Occhipinti-Ambrogi, A., 2016. East is east and west is west? Management of marine bioinvasions in the Mediterranean Sea. Estuar. Coast. Shelf Sci. 2016. https://doi.org/10.1016/j.ecss.2015.12.021.

Genovesi, P., 2001. Guidelines for Eradication of terrestrial vertebrates: a European Contribution to the Invasive Alien Species Issue. In: Other Publications in Wildlife Management. Paper 24.

Gollasch, S., Minchin, D., David, M., 2015. The transfer of harmful aquatic organisms and pathogens with ballast water and their impacts. In: David, M., Gollasch, S. (Eds.), Global Maritime Transport and Ballast Water Management. Invading Nature-Springer Series in Invasion Ecology. Vol. 8. pp. 35-58. https://doi.org/10.1007/978-94-0179367-4_3.

Grosholz, E., 2002. Ecological and evolutionary consequences of coastal invasions. Trends Ecol. Evol. 17, 22-27. https://doi.org/10.1016/S0169-5347(01)02358-8.

Hayes, K., Hewitt, C.L., 2000. Risk assessment framework for ballast water introductions Volume II. In: Centre for Research on Introduced Marine Pests, Technical Report No. 21. CSIRO Marine Research Hobart, Australia.

HELCOM/OSPAR, 2015. HELCOM-OSPAR joint harmonized procedure for BWMC A-4 exemptions. In: Annex 2 - Detailed description of the Port Survey Protocol. HELCOM MARITIME 15-2015. Klaipeda, Lithuania, 23-25 November 2015, (52 pp).

Hewitt, C.L., 2002. The distribution and diversity of tropical Australian marine bio-invasions. Pac. Sci. 56, 213-222. https://doi.org/10.1353/psc.2002.0016.

Hewitt, C.L., Martin, R.B., 2001. Revised protocols for baseline port surveys for in troduced marine species: survey design, sampling protocols and specimen handling. In: Centre for Research on Introduced Marine Pests. Technical Report No. 22. CSIRO Marine Research, Hobart (46 pp).

Hewitt, C.L., Campbell, M.L., Thresher, R.E., Martin, R.B., 1999. Marine biological invasions of Port Phillip Bay, Victoria. In: CSIRO CRIMP Technical Report No. 20. Centre for Research on Introduced Marine Pests, Hobart, Tasmania, Australia (344 pp).

Hewitt, C.L., Campbell, M.L., Gollasch, S., 2006. Alien Species in Aquaculture. Considerations for Responsible Use. Vol. viii IUCN, Gland, Switzerland and Cambridge, UK (32 pp).

IMO, 2004. International Convention for the Control and Management of Ships' Ballast Water and Sediments. 13. International Maritime Organization, London, UK, pp. 36.

IMO, 2005. Guidelines for Ballast Water Management and Development of Ballast Water Management Plan (G4). Marine Environment Protection Committee, Resolution MEPC. Vol. 127 (53) International Maritime Organization, London, UK 22 July 2005. (16 pp).

Katsanevakis, S., Wallentinus, I., Zenetos, A., Leppäkoski, E., Çinar, M.E., Oztürk, B., Grabowski, M., Golani, D., Cardoso, A.C., 2014. Impacts of marine invasive alien species on ecosystem services and biodiversity: a pan-European review. Aquat. Invasions 9, 391-423. https://doi.org/10.3391/ai.2014.9.4.01.

Kettunen, M., Genovesi, P., Gollasch, S., Pagad, S., Starfinger, U., ten Brink, P., Shine, C., 2009. Technical Support to EU Strategy on Invasive Alien Species (IAS) - Assessment of the Impacts of IAS in Europe and the EU. Institute for European Environmental Policy, Brussels.

Kish, L., 1995. Survey Sampling. Wiley Classics Library Edition, New York (643 pp).

Kraus, R., Grilli, F., Supić, N., Janeković, I., Brailo, M., Cara, M., Cetinić, A., Campanelli, A., Cozzi, S., D'Adamo, R., Djakovac, T., Dutour-Sikirić, M., Flander Putrle, V., France, J., Joksimović, D., Klun, K., Kolitari, J., Kralj, M., Kušpilić, G., Marini, M., Matić, F., Mikus, J., Ninčević-Gladan, Ž., Pansera, M., Pećarević, M., Precali, R., Prusina, I., Relitti, F., Santucci, A., Specchiulli, A., Škalic, D., 2018. Oceanographic Characteristics of the Adriatic Sea - Support to Secondary Spread of HAOP by Natural Dispersal. (This issue).

Lodge, D.M., Williams, S., MacIsaac, H.J., Hayes, K.R., Leung, B., Reichard, S., Mack, R.N., Moyle, P.B., Smith, M., Andow, D.A., Carlton, J.T., McMichel, A., 2006. Biological invasions: recommendations for US policy and management. Ecol. Appl. 16, 2035-2054. https://doi.org/10.1890/1051-0761(2006)016[2035:BIRFUP]2.0. CO;2.

Luna, G.M., Manini, E., Turk, V., Tinta, T., D'Errico, G., Baldrighi, E., Baljak, V., Buda, D., Cabrini, M., Campanelli, A., Cenov, A., Del Negro, P., Drakulović, D., Fabbro, C., Glad, M., Grilec, D., Grilli, F., Jokanović, S., Jozić, S., Kauzlarić, V., Kraus, R., Marini, M., Mikuš, J., Milandri, S., Pećarević, M., Perini, L., Quero, G.M., Šolić, M., Vukić Lušić, D., Zoffoli, S., 2018. Status of Faecal Pollution in Ports: A Basin-wide Investigation in the Adriatic Sea. (This issue).

Marchini, A., Galil, B.S., Occhipinti-Ambrogi, A., 2015. Recommendations on standardizing lists of marine alien species: lessons from the Mediterranean Sea. Mar. Pollut. Bull. 10, 267-273. https://doi.org/10.1016/j.marpolbul.2015.09.054.

McDonald, L.L., 2004. Sampling rare populations. In: Thompson, W.L. (Ed.), Sampling Rare or Elusive Species. Concepts, Designs and Techniques for Estimating Population Parameters. Island Press, Washington, DC, pp. 11-42.

Minchin, D., Davis, M.H., Davis, M.E., 2006. Spread of the Asian tunicate Styela clava Herdman, 1882 to the east and south-west coasts of Ireland. Aquat. Invasions 1 , 91-96. https://doi.org/10.3391/ai.2006.1.2.7.

Mozetič, P., Cangini, M., Francé, J., Bastianini, M., Bernardi Aubry, F., Bužančić, M.
Cabrini, M., Cerinoe, F., Čalić, M., D'Adamo, R., Drakulović, D., Finotto, S., Fornasaro, D., Grilli, F., Kraus, R., Kužat, N., Marić Pfannkuchen, D., Ninčević Gladan, Ž., Pompei, M., Rotter, A., Servadei, I., Skejić, S., 2018. Phytoplankton Diversity in Adriatic Ports: Lessons From the Port Baseline Survey for the Management of Harmful Algal Species. (This issue).

Ninčević Gladan, Ž., Magaletti, E., Scarpato, A., Azzurro, E., Bacci, T., Berto, D., Dulčić, J., Gennaro, P., Marusso, V., Penna, M., Rampazzo, F., Rende, F.S., Romanelli, G., Vidjak, O., Trabucco, B., Žuljević, A., 2014. BALMAS Port Baseline Survey Protocol. Protocol. BALMAS Project. Work Package 5.1. (28 pp).

Ninčević Gladan, Ž., Vidjak, O., Žuljević, A., Šolić, M., Cvitković, I., Matić Skoko, S., 2016. Port Baseline Survey. (Final Report) BALMAS project. WP5. Activity 5.1. (31 pp).

Olenin, S., Alemany, F., Cardoso, A.C., Gollasch, S., Goulletquer, P., Lehtiniemi, M., McCollin, T., Minchin, D., Miossec, L., Occhipinti Ambrogi, A., Ojaveer, H., Jensen, K.R., Stankiewicz, M., Wallentinus, I., Aleksandrov, B., 2010. Marine Strategy Framework Directive - Task Group 2 Report. Nonindigenous Species. Office for Official Publications of the European Communities, Luxembourg978-92-79-15655-7 (EUR 24342 EN ISSN 1018-5593).

Olenin, S., Narščius, A., Minchin, D., David, M., Galil, B., Gollasch, S., Marchini, A., Occhipinti-Ambrogi, A., Ojaveer, H., Zaiko, A., 2014. Making non-indigenous species information systems practical for management and useful for research: an aquatic perspective. Biol. Conserv. 173, 98-107. https://doi.org/10.1016/j.biocon.2013.07. 040.

Olenin, S., Ojaveer, H., Minchin, D., Boelens, R., 2016. Assessing exemptions under the ballast water management convention: preclude the Trojan horse. Mar. Pollut. Bull. 103, 84-92. https://doi.org/10.1016/j.marpolbul.2015.12.043.

Paulay, G., Kirkendale, L., Lambert, G., Meyer, C., 2002. Anthropogenic biotic interchange in a coral reef ecosystem: a case study from Guam. Pac. Sci. 56, 403-422. http://hdl.handle.net/10125/2625.

Pedersen, J., Bullock, R., Carlton, J., Dijkstra, J., Dobrroski, N., Dyrynda, P., Fisher, R., Harris, L., Hobbs, N., Lambert, G., Lazo-Wasem, E., Mathieson, A., Miglietta, M., Smith, J., Smith, J., Tyrrell, M., 2003. Marine Invaders in the Northeast. Rapid Assessment Survey of Non-native and Native Marine Species of Floating Dock Communities. MIT Sea Grant College Program Publication No. 05-3 (41 pp). http:// massbay.mit.edu/exoticspecies/exoticmaps/RAS-report11.pdf (accessed 28.09.06).

Perini, F., Bastianini, M., Capellacci, S., Pugliese, L., DiPoi, E., Cabrini, M., Buratti, S., Marini, M., Penna, A., 2018. Molecular Methods for Cost-efficient Monitoring of HAB (Harmful Algal Bloom) Dinoflagellate Resting Cysts. (This issue).

Petrocelli, A., Antolić, B., Bolognini, L., Cecere, E., Cvitković, I., Despalatović, M., Falace, A., Finotto, S., Iveša, L.J., Mačić, V., Marini, M., Orlando-Bonaca, M., Rubino, F., Trabucco, B., Žuljević, A., 2018. Port Baseline Biological Surveys and Seaweed Bioinvasions in port areas: What's the matter in the Adriatic Sea? (This issue).

Romanelli, G., Berto, D., Calace, N., Amici, M., Maltese, S., Formalewicz, M., Campanelli, A., Marini, M., Magaletti, E., Scarpato, A., 2018. Ballast Water Management System: Assessment of Chemical Quality Status of Several Ports in Adriatic Sea. (This issue).

Ruiz, G.M., Hewitt, C.L., 2002. Toward understanding patterns of coastal marine invasions: a prospectus. In: Leppäkoski, E., Gollasch, S., Olenin, S. (Eds.), Invasive Aquatic Species of Europe Distribution, Impact and Management. Kluwer Academic Publishers, Dordrecht, pp. 529-547.

Ruiz, G.M., Fofonoff, P.W., Carlton, J.T., Wonham, M.J., Hines, A.H., 2000. Invasion of coastal marine communities in North America: apparent patterns, processes, and biases. Annu. Rev. Ecol. Syst. 31, 481-531. https://doi.org/10.1146/annurev. ecolsys.31.1.481.

Semprucci, F., Baldrighi, E., Franzo, A., Cvitkovic, I., Bogner, D., Despalatovic, M., Berto, D., Formalewicz, M.M., Scarpato, A., Frapiccini, E., Marini, M., Grego, M., 2018. Meiofaunal Community in the Adriatic Harbors: Baseline Data for Future Risk Assessment in the Ballast Water Management. (This issue).

Spagnolo, A., Auriemma, R., Bacci, T., Balković, I., Bertasi, F., Bolognini, L., Cabrini, M., Cilenti, L., Cuicchi, C., Cvitković, I., Despalatović, M., Grati, F., Grossi, F., Jaklin, A., Lipej, L., Marković, O., Mavrič, B., Mikac, B., Nasi, F., Nerlović, V., Pelosi, S., Penna, M., Petović, S., Punzo, E., Santucci, A., Scirocco, T., Strafella, P., Trabucco, B., Travizi, A., Žuljević, A., 2018. Non-indigenous Macrozoobenthic Species on Hard Substrata of Selected Harbours in the Adriatic Sea. (This issue).

Travizi, A., Balković, I., Bacci, T., Bertasi, F., Cuicchi, C., Flander-Putrle, V., Grati, F., Grossi, L., Jaklin, A., Lipej, L., Mavrič, B., Mikac, B., Marusso, V., Montagnini, L., Nerlović, V., Penna, M., Salvalaggio, V., Scirocco, T., Trabucco, B., Spagnolo, A., 2018. Macrozoobenthos in The Adriatic Sea Ports: Soft Bottom Communities with an Overview of Non-indigenous Species. (This issue. Under review).

Vidjak, O., Bojanić, N., de Olazabal, A., Benzi, M., Brautović, I., Camatti, E., Hure, M. Lipej, L., Lučić, D., Pansera, M., Pećarević, M., Pestorić, B., Pigozzi, S., Tirelli, V., 2018. Zooplankton in Adriatic Port Environments: Indigenous Communities and Nonindigenous Species. (This issue).

Vitousek, P.M., D'Antonio, C.M., Loope, L.L., Westbrooks, R., 1996. Biological invasions as global environmental change. Am. Sci. 84, 468-478.

Wyatt, A.S.J., Hewitt, C.L., Walker, D.I., Ward, T.J., 2005. Marine introductions in the Shark Bay world heritage property, Western Australia: a preliminary assessment. Divers. Distrib. 11, 33-44. https://doi.org/10.1111/j.1366-9516.2005.00109.x. 